\title{
Growing Pains: International Instability and Equity Market Returns
}

We use the ratio of growth in global military expenditures to GDP to capture ex ante expectations of political instability and explore the relation between this measure and returns. In a standard global asset pricing framework with 44 countries, this measure helps to explain cross-country return differences. Furthermore, emerging countries have greater exposure to the international political instability risk than developed countries. This partially explains the higher returns observed in emerging countries.

Zhuo Chen is an Assistant Professor of Finance at the PBC School of Finance, Tsinghua University in Beijing, China 100083.

Andrea Y. Lu is a Senior Lecturer of Finance at the University of Melbourne in Melbourne, 3010, Australia.

Zhuqing Yang is a Postdoctoral Associate at the MIT Sloan School of Management in Cambridge, MA 02139.

We thank an anonymous referee, Marc Lipson (Editor), Snehal Banerjee, Geert Bekaert (discussant), Jules van Binsbergen, Jonathan Brogaard, Jason Chen, Anna Cieslak, Zhi Da, Paul Gao, Ravi Jagannathan, Heikki Lehkonen (discussant), Christian Lundblad (discussant), Dimitris Papanikolaou, Jonathan Parker, Christophe Spaenjers (discussant), Annette Vissing-Jorgensen,

Bohui Zhang (discussant), and seminar participants at the 3rd Luxembourg Asset Management Summit, the 2014 China International Conference in Finance, the $24^{\text {th }}$ Annual Conference on 
Financial Economics and Accounting, the 2013 FMA Annual Conference, the Midwest Finance Association 2013 Annual Meeting, the $25^{\text {th }}$ Australasian Finance and Banking PhD Forum and conference, and the Kellogg Finance Bag Lunch for helpful comments. This paper has benefited from the visitor program of the Centre for Asian Business and Economics at the Faculty of Business and Economics of the University of Melbourne. The authors are responsible for any remaining errors. 
Stock market returns differ across countries and these differences are especially large between emerging and developed countries. Many international asset pricing models have been proposed to explain this cross-country variation including the world CAPM (Cumby and Glen, 1990; Harvey, 1991; Ferson and Harvey, 1993, 1994), the global exchange rate risk model (Dumas and Solnik, 1995), and others. Meanwhile, global financial markets seem to be connected via political events. When global/regional political events occur, international stock markets tend to respond accordingly. For example, when North Korea's nuclear bomb testing took place on May 25, 2009, not only did surrounding countries' (e.g., Japan, South Korea) stock markets fall, other markets also fell. Emerging markets seem to be more susceptible to political events when compared to developed markets. To complement existing international asset pricing models, we investigate this political tie and propose an instability risk measure that is associated with the constantly evolving international political tensions and conflicts. We find that countries' exposures to the instability risk are reflected in their stock market returns. In addition, these differences in exposure also partially explain the return spread between developed and emerging markets.

Rather than reviewing the impact of actual political events on financial markets, we recognize that investors' perceptions of risk can elevate prior to the occurrence of crises and such change in perception could affect assets' risk premia ex ante. ${ }^{1}$ As argued by Jackson (2009), wars that "did not happen" might have disturbed investors and affected macroeconomic performance. The actual occurrence of wars may not be a good indicator of the presence of international

\footnotetext{
${ }^{1}$ Most studies in this area adopt a case study approach and focus primarily on the impact on the parties that are closely involved in the event. Willard, Guinnane, and Rosen (1996) analyze events that took place during the U.S. Civil War, Bittlingmayer (1998) studies the movement of stock volatility in Germany during the transition from Imperial to Weimar Germany, Frey and Kucher $(2000,2001)$ investigate the impact of events surrounding the World War II on European participating countries' government bond prices, and Zussman, Zussman, and Nielsen (2008) examine the financial market's reaction in both Israel and the Palestinian Authority to the outbreak of the Intifada in 2000. In addition, Leigh, Wolfers, and Zitzewitz (2003) study the impact of the war with Iraq on U.S. equities. All of these studies present an important notion that the occurrence of crises has a significant impact on the financial markets. Some of the other literature use elections to identify shocks to a country's political risk and study its relation with corporate investment and stock abnormal returns including Durnev (2010), Julio and Yook (2012), Pantzalis, Stangeland, and Turtle (2000), and Gao and Qi (2013).
} 
instability. A nuclear war never eventuates, but the arms race between the Soviet Union and the U.S. during the Cold War greatly affected investors' perceptions of risk. Thus, in this paper, we emphasize the political instability risk associated with constantly evolving political tensions and conflicts, and investigate how such risk affects international asset prices.

We propose a measure for international instability risk by taking insight from the burgeoning research on strategic militarization and international conflicts. Military expansion, which often serves as an early indication of the threat of war, has been constantly shaping the outcomes of international interaction, as well as countries' political and economic policies. As argued by Jackson and Morelli (2011), wars are costly and risky, so rational states have incentives to negotiate a settlement that is preferred to the gamble of war. Militarization is often used to signal the governments' inclination toward war or different understandings of the underlying state of the world (Chassang and Miquel, 2010). In addition, militarization changes the final payoff of a hypothetical war and serves as a commitment mechanism that makes the threat of war credible (Fearon, 1997). For either reason, countries find ways to mold international bargaining in peacetime through strategic militarization.

We capture international instability risk using the growth of global total military expenditures as a percentage of total GDP. This proxy captures the simple idea that any increase in military expenditures could potentially lead to an increase in the probability of a crisis and/or an increased destructiveness should a crisis does occur. Thus, an escalation in global militarization may cause uneasiness in the stock market and rational investors could factor in this impact when they make investment decisions. To the best of our knowledge, our paper is the first to study the implications of countries' militarization on asset prices.

Our empirical results support our hypothesis. First, using 44 country stock indices, we find that international instability risk (IIR), proxied by the growth of global militarization, is a valid 
systematic risk factor in international stock markets. The cross-country pricing power of international instability risk survives after controlling for other pricing factors including the world market return, the exchange rate factor, global production shocks, and global fiscal policy shocks. In addition, we find that higher returns observed in emerging countries are associated with greater exposure to international instability risk. Moreover, we find that international instability risk is more likely to affect international stock markets through the consumption channel, but less likely through the actual occurrence of wars. Meanwhile, countries' exposure to international instability risk is related with their local political stability. Our results are robust to other alternative specifications of IIR or excluding financial crisis periods. Finally, consistent with the U.S. stock market's low exposure to international instability risk, we find little evidence that international instability risk affects the cross section of returns in the U.S.

Our findings are consistent with the theoretical predictions of the time-varying rare disaster risk (Rietz, 1988; Barro, 2006). Our paper also complements previous empirical findings (Gabaix, 2012; Gourio, 2012; Wachter, 2013), who demonstrate that changes in the probability of rare disasters affect stock market prices. The most related paper to ours is Berkman, Jacobsen, and Lee (2011), in which the authors construct a time-varying proxy for rare disaster probability using the number of political crises and study its impact on (mostly developed markets) stock returns. Aligning with their ideas, we push the argument further and review investors' perception of risk formed via the ongoing changes in militarization levels, which may or may not involve the actual occurrence of a crisis. In addition, while they emphasize the contemporaneous impact of rare disaster risk on stock market performance, we focus on the inference of an international instability risk premium and the explanation for the large return differences between developed and emerging markets.

Another relevant line of literature examines policy uncertainty and asset prices. On the 
theory side, Pastor and Veronesi $(2012,2013)$ find that political uncertainty is priced through a learning channel even if the policy shock itself is orthogonal to economic fundamentals. Other papers focus on the implications of fiscal policy uncertainty on asset prices (Gomes, Michaelides, and Polkovnichenko, 2013; Croce, Nguyen, and Schmid, 2012; Croce, Kung, Nguyen, and Schmid, 2012). On the empirical side, Baker, Bloom, and Davis (2015) develop an index to measure policy uncertainty and find that an increase in policy uncertainty is associated with declines in aggregate outcomes, private investment, and aggregate employment. Following Baker et al. (2015), Brogaard and Detzel (2015) construct a country-by-country economic policy uncertainty index and find that innovation in economic policy uncertainty earns a negative risk premium. ${ }^{2}$ Their finding is consistent with ours, while distinction exists in the two types of risk. Their index captures countrylevel economic policy uncertainty, while ours measures the risk associated with cross-country political tensions and instability. Our findings generalize theirs in the sense that economic policies could potentially be shaped by international instability. Investors foresee these impacts and demand return compensation for exposure to such risk.

Military expenditure data have been previously employed by researchers to study government fiscal policy and macro-economies (Ramey and Sharpiro, 1998; Burnside, Eichenbaum, and Fisher, 2004; Fish and Peters, 2010; Berndt, Lustig and Yeltekin, 2012). Different from our study, these papers employ U.S. military expenditures as an instrument for fiscal policy shocks. In a later section of this paper, we demonstrate that instability risk is different from fiscal policy shocks, and the instability risk premium remains when fiscal policy shocks are controlled for.

The rest of the paper is organized as follows. In Section I, we describe the data and construct the proxy for international instability risk. We investigate the cross-sectional implications

\footnotetext{
${ }^{2}$ Belo and $\mathrm{Yu}$ (2013) find that large government investment in public sector capital forecasts high aggregate stock market returns at both the short and long horizons in the U.S. Belo, Gala, and Li (2013) find that conditional upon presidential cycles, stock returns are related to firms' exposure to government spending. Sialm (2009) studies the crosssectional and time series asset pricing implications of tax changes and finds that stocks with higher tax burdens tend to offer higher before tax returns.
} 
of political instability risk on stock returns in Section II. Additional results are presented in Section III, while Section IV provides our conclusions.

\section{Data}

This section provides details regarding the two major datasets used in our paper. Descriptions of the international stock market data is presented in Section A. Details of the construction of the international instability risk proxy are explored in Section B. For brevity, we leave the detailed description of other data to the corresponding sections and Section I of the appendix.

\section{A. Stock Market Data}

Data regarding international equity market returns comes from Morgan Stanley Capital International (MSCI). Our data include country-level equity market indices for 44 countries, as well as two aggregate equity indices: 1) one for the emerging markets and 2) one for the developed markets. Annual returns in USD are computed using gross indices with dividends. To maximize data length, we use "Standard Indices" that are based on large and mid-cap stocks, representing approximately $85 \%$ of total market capitalization.

Table I presents the descriptive statistics. The excess return series includes 23 developed country indices, 21 emerging country indices, as well as two value-weighted aggregate indices: 1) the World Index (WI), which covers 23 developed countries and 2) the Emerging Markets Index (EMI) that covers 21 emerging countries. To avoid confusion, we refer to the World Index as the Developed Markets Index (DMI) hereinafter. To compute excess returns, we subtract the onemonth U.S. Treasury bill rate from gross returns, assuming that investors are global investors who take the U.S. risk free rate as the opportunity cost. 
Insert Table I about here.

The cross-sectional variation in countries' excess returns and the significant difference between emerging and developed markets are illustrated in the descriptive statistics. Emerging countries, in general, have higher returns than developed countries. Specifically, the EMI has an average annual excess return of $14.05 \%$ from $1988-2013$, while the number for the DMI is $5.28 \%$ over the same period and $6.18 \%$ over the full sample period of $1970-2013$.

\section{B. The International Instability Risk Proxy}

Literature regarding strategic militarization and international conflicts argues that military expansion has been constantly shaping the outcomes of international interaction, as well as countries' political and economic policies. While wars rarely occur in the modern era, through strategic militarization, states find a way to continue molding international relationship in peacetime. Any changes in military power could potentially lead to changes in countries' policies and the outcomes of international bargaining.

We measure international instability using the growth of worldwide militarization. An escalation in global military expansions contributes to international instability in two ways. First, it increases the probability of a crisis. In addition, the impact of a hypothetical war increases (i.e., the damage would be larger if a crisis ever occurs). Either channel could affect investors' perception of risk when investing in global stock markets.

We refer to the proxy as the instability risk factor and denote it as IIR for convenience. The definition is presented in Equation (1) with notations summarized in Panel A of Table II. IIR is computed as the growth rate of global militarization under the beginning-of-period convention, 
where the global militarization level in a given year is measured by the sum of military expenditures across all countries scaled by the total GDP for those countries in the same year. Our choice of using the beginning-of-period convention is consistent with the rationale for its wide adoption in the consumption-based asset pricing literature (Campbell, 1999; Campbell, 2003; Yogo, 2006; Savov, 2011) as it allows better matching between the risk factor and movement in stock returns. $^{3}$

$$
I I R_{t}=\frac{\operatorname{MilGDP}_{t+1}}{\operatorname{MilGDP}_{t}}, \text { where MilGDP } P_{t}=\frac{\sum_{i=1}^{N_{t}} M i l_{i, t}}{\sum_{i=1}^{N_{t}} G D P_{i, t}}
$$

Annual country level military expenditures come from two sources. The Inter-University Consortium for Political and Social Research (ICPSR) database provides expenditure data in nominal USD from 1970-1989 and the Stockholm International Peace Research Institute (SIPRI) database provides data in constant 2009 USD from 1990-2014. Both datasets collect their military expenditure data based on open sources including official government data and government responses to questionnaires sent out by international organizations (e.g., the United Nations). We convert country-level military expenditure data into current USD using the U.S. price deflator and aggregate them into a global military expenditure measure by adding all countries with available data in that year. ${ }^{4}$ The global military expenditure is then scaled by the sum of GDP, taken over the same list of countries in that year to ensure consistency. GDP data are from the ICPSR database from 1970-1989 and from the World Bank Development Indicators from 1990 onward. The number of countries with available military expenditure varies, ranging from a minimum of 113 in 1989 to a maximum of 153 in 2003.

\footnotetext{
${ }^{3}$ The IIR measured under the beginning-of-period convention is strongly correlated with the excess returns of the EMI $(-30.9 \%)$ and the DMI $(-19.1 \%)$. In contrast, the correlation between IIR constructed under the end-of-period convention and stock market returns are almost zero $(2.5 \%$ and $0.9 \%)$.

${ }^{4}$ The price deflator is constructed using the Personal Consumption Price Index in Item 2 of NIPA Table 1.1.4.
} 
Insert Table II about here.

We scale the total military expenditures by GDP for several reasons. First, by applying the scaling, militarization of each year is measured as the proportion of total available global resources. This scaling is especially important in our study when the number of countries with military expenditure data changes over time. In addition, since both military expenditures and GDP can be influenced by aggregate economic conditions, the scaling mitigates the potential impact of factors that affect both (e.g., business cycles). Moreover, scaling frees us from adjusting for inflation.

Panel B of Table II presents the descriptive statistics of the instability risk factor IIR. The factor has a mean of $-2.3 \%$ and a standard deviation of $5.8 \%$ over the sample period from 19702013. It has a first order autocorrelation coefficient of 0.32. Panel C of Table II reports the correlations between IIR and several economic and financial variables. IIR has a correlation of $-19.06 \%$ with the DMI, while the correlation is $-30.91 \%$ with the EMI. IIR has a small and negative correlation with the growth of global GDP per capita (-5.91\%). IIR has a positive correlation with the growth rate of the global debt to GDP ratio (27.03\%), the dollar factor that captures the U.S. dollar exchange rate change (16.51\%), and the VIX uncertainty measure $(31.87 \%)$. These positive correlations suggest that higher growth in militarization often occurs in periods with a faster accumulation of government debt and also when market uncertainty is higher. Figure I plots the time series of IIR, along with excess returns of two MSCI aggregate indices.

Insert Figure I about here.

\section{Instability Risk and Equity Risk Premia}




\section{A. Cross Country Analysis: The Benchmark Model}

To examine whether international instability risk (IIR) affects stock returns across various countries, we consider a single factor model that links the countries' expected returns to their exposure to IIR:

$$
E\left(R_{i, t}^{e}\right)=\beta_{i} \lambda
$$

where $R_{i, t}^{e}$ is country $i$ 's excess return, $\beta_{i}$ is country $i$ 's risk loading on IIR, and $\lambda$ is the market price of risk associated with IIR. ${ }^{5}$

We obtain estimates for $\beta_{i}$ and $\lambda$ by running the standard Fama-MacBeth (1973) two-step regressions. Specifically, we first conduct time series regressions of excess returns on IIR. We then run a cross-country regression for every year $t$ to obtain the market price of risk $\lambda_{t}$. The price of risk $\lambda$ is the time series average of $\lambda_{t}$. The procedure is specified in Equations (3)-(5).

$$
\begin{aligned}
& R_{i, t}^{e}=\alpha_{i}+\beta_{i} I I R_{t}+\epsilon_{i, t} \\
& R_{i, t}^{e}=\lambda_{0, t}+\beta_{i} \lambda_{t}+\eta_{i, t} \\
& \hat{\lambda}=\frac{1}{T} \sum \hat{\lambda}_{t}
\end{aligned}
$$

Panel A in Table III presents factor loadings estimated from the first-step regression, while

\footnotetext{
${ }^{5}$ Using 44 country market returns as test assets mitigates the possible impact of the critique noted by Lewellen, Nagel, and Shanken (2010) regarding how pricing power can be exaggerated when there is a clear covariance structure among the test assets. We extract the first three principal components of those 44 country market returns and compute the $R^{2}$ of the Fama-MacBeth (1973) regressions using those three principal components as testing assets. We find that the cross-sectional adjusted $R^{2}$ is only $16 \%$ suggesting that there is little evidence of covariance structure among countries market returns.
} 
Panel B reports the market price of IIR estimated from the second-step regression. A few findings are worth emphasizing. First, all of the countries have negative loadings on IIR suggesting that adverse shocks to international instability lead to negative contemporaneous returns. In addition, the magnitude and significance of the exposure is larger for emerging countries than developed countries. Furthermore, international instability risk is priced. The market price of risk $\hat{\lambda}$ is -4.65 with a $t$-statistic of 2.07. The cross-sectional pricing power of IIR can be more easily seen in Figure II where we plot countries' risk loadings $\beta_{i}$ against their realized excess returns. The solid dots indicate countries with statistically significant exposure and empty dots otherwise. The exposure aligns well with the realized returns. Additionally, emerging countries, on average, have greater exposure to IIR and, as such, higher returns than developed markets.

Insert Table III and Figure II about here.

The negative price of risk and negative risk loadings result in positive risk premia associated with international instability risk. A country with large negative exposure to instability risk is expected to experience lower returns when the negative event occurs (this is the time when instability risk is high). As a result, rational investors demand a higher risk premium for holding stocks in this country ex ante. Risk premia are higher for countries with larger exposure, namely, emerging countries. Thus, international instability risk contributes to higher returns for emerging countries.

The risk compensation of IIR for each country is calculated as $\beta_{i} \lambda$. Among developed countries, the median risk compensation for IIR is $3.8 \%$ per year (Switzerland) and the average value is $4.4 \%$. In terms of its explanatory power, IIR, on average, contributes to $52 \%$ of developed countries' market returns with the median as $48 \%$ for Australia. IIR plays a more important role in 
explaining aggregate country risk premia in emerging countries. The average risk compensation for IIR in emerging countries is $14.8 \%$ per year with a median of $12.7 \%$ (Indonesia). Typically, $84 \%$ of emerging countries' market returns can be explained by IIR with the median as $75 \%$ for Turkey. We acknowledge that these numbers are likely to be on the higher end of the estimates for IIR's explanatory ability due to possible measurement errors. However, they still provide us with guidance as to the importance of IIR in generating cross-country return differences, especially across developed and emerging countries.

Note that two emerging countries, Poland and Turkey, have significantly higher exposure. Poland has a loading of -9.96 and Turkey has a loading of -6.77 . To ensure that our results are not driven by these two outliers, we repeat the test with 42 MSCI country indices excluding these two countries. The estimated price of the instability risk is similar to the one in the benchmark case, as shown in Appendix Table A1.

Due to the unbalanced nature of the country-level stock returns data, countries' exposure to IIR is estimated over periods with different starting years. However, we find that the negative price of risk of the IIR and the significant loadings for emerging countries still remain over a shorter sample (1988-2013) using countries with balanced return data over this period. It is true that the statistical power of the estimate decreases in the balanced subsample. The shortened time series is likely to be responsible for this weakening in statistical power. The results are available upon request.

\section{B. Instability Risk Exposure of Emerging and Developed Markets}

The evidence above indicates that international equity markets are exposed to international instability risk and exposure to such risk, in general, is higher for emerging countries than for developed countries. To more carefully quantify this difference in exposure, we implement a GMM 
estimation using the two aggregate indices, the Emerging Markets Index (EMI) and the Developed Markets Index (DMI), as test assets. We adopt the GMM procedure for two reasons. First, the original two-pass Fama-MacBeth (1973) procedure does not apply when the number of test assets is small. In addition, the GMM procedure allows the risk loadings and market price of risk to be estimated simultaneously, bypassing the variance-in-error problem for the estimated standard error. We choose the moment conditions following Jagannathan and Wang (2002):

$$
E\left[\begin{array}{c}
R^{e}-\beta^{\prime}\left(\lambda-\mu+I I R_{t}\right) \\
\left(R^{e}-\beta^{\prime}\left(\lambda-\mu+I I R_{t}\right)\right) I I R_{t} \\
\mu-I I R_{t}
\end{array}\right]=\left[\begin{array}{l}
0 \\
0 \\
0
\end{array}\right] .
$$

Parameters to be estimated are the same as previously: indices' exposure $\beta$ to the instability risk and the market price of risk $\lambda$. We find an over-identified GMM estimation with five moment conditions and four parameters. As the sample for DMI is longer than EMI, we address the unbalanced sample issue by implementing the adjusted GMM procedure of Lynch and Wachter (2013). Details are presented in Section II of the appendix.

Estimation results using the two aggregate indices are consistent with that of the cross country analysis. The price associated with the instability risk is negative and statistically significant $(\lambda=-8.40, t$-statistic $=-2.78)$. While both developed markets and emerging markets have significant loadings on international instability risk, the exposure for emerging markets is greater in economic magnitude (-1.59 vs. -0.72). Specifically, a one standard deviation increase in IIR, on average, leads to a $9.22 \%$ decrease in the excess return for emerging markets, but only a $4.18 \%$ decrease for developed markets. However, a formal Wald test of $\beta_{D}=\beta_{E}$ yields a $p$-value of 0.74 indicating that the factor loading difference between developed and emerging markets is not statistically significant. The lack of significance is likely due to the relatively short sample 
coverage in the time series.

Insert Table IV about here.

\section{Channels}

As stated earlier, the instability risk that we attempt to capture is related to the constantly evolving political tensions and conflicts among countries. Such risk could potentially lead to changes in countries' policies and outcomes of international bargaining. The previous section provides evidence that international instability risk is priced in international stock markets. In this section, we examine the potential channels through which the instability risk affects stock markets.

One channel could be through the variations in households' consumption. The vast number of consumption-based capital asset pricing models suggests that consumption growth helps to explain cross-sectional equity premia (Breeden, 1979; Lucas, 1978; Mehra and Prescott, 1985; Bansal and Yaron, 2004). Some researchers also find that rare disasters could have severe impacts on household consumption (Rietz, 1988; Barro, 2006). To test whether instability risk affects households' consumption choices, we examine the correlation between IIR and unexpected worldwide consumption growth.

Data on real consumption per capita are from the World Bank Development Indicators. The World Bank classifies countries into four groups based on their Guaranteed Minimum Income (GMI) per capita. The four groups are low income countries, middle income countries, high income non-OECD countries, and high income OECD countries. Twenty-two of 23 MSCI developed markets belong to the "high income OECD" group and a majority of the emerging countries in the MSCI Emerging Markets Index meet the definition for the "middle income" group. Thus, we examine the correlation between IIR and the unexpected consumption growth of these two groups. 
Consumption growth is calculated using the beginning-of-period convention and the unexpected component is the $\mathrm{AR}(1)$ residual. We find that the proposed IIR factor is significantly correlated with the unexpected consumption growth of middle income countries with a correlation of $-30 \%(p$-value $=0.05)$. On the other hand, no correlation exists between the IIR factor and the unexpected consumption growth of high income OECD countries. This finding suggests that instability risk could affect asset prices by distorting households' consumption choices in emerging countries.

Another channel could be the actual occurrence of wars. Under this hypothesis, instability risk reflects the magnitude of wars that affect the potential for major destruction in productivity. We approximate the magnitude of wars by the number of deaths caused by inter-state and extrastate wars globally and examine its correlation with IIR factor. Data are from the Correlates of War Database. We find little evidence. The correlation between the IIR factor and the magnitude of wars is not significant. This finding suggests that the occurrence of wars is unlikely to be a channel as to how instability risk affects stock markets. However, it is consistent with our conjecture that in the relatively peaceful time we currently reside in, instability can arise without the actual occurrence of wars.

To understand the determinants of countries' exposure to international instability risk, we examine the relation between estimated exposure and country-level characteristics including political stability, foreign asset holdings, and trade intensity. To measure countries' political stability, we adopt the ratings published by the International Country Risk Guide (ICRG). The ICRG contains political risk ratings for 140 countries since 1979 . The company collects political information data on each country and converts it into risk points for each of the 12 individual risk components. ${ }^{6}$ The objective of these ratings is to reflect the stability of government policies and the

\footnotetext{
${ }^{6}$ The risk components include government stability, socioeconomic conditions, investment profiles, internal conflict,
} 
strength of the legal system. These ratings have been adopted by previous studies to examine the relation between countries' local political risk and the financial markets (Erb, Harvey, and Viskanta, 1996; Boutchkova, Doshi, Durnev, and Molchanov, 2012; Bekaert, Harvey, Lundblad, and Siegel, 2014). We find that countries' exposure to IIR are correlated with countries' political risk. The correlations between countries' IIR betas and their average political risk ratings are positive for all 12 components and significant for eight of 12 components. ${ }^{7}$ The positive and significant correlations suggest that countries with low political stability are more likely to be vulnerable to international instability.

We also calculate the correlations between countries' exposure to IIR and foreign asset holdings, as well as foreign trade intensity. We scale a country's net foreign assets and its net trade by GDP. We do not find any evidence that these two characteristics help to explain the crosscountry difference in exposure to IIR.

\section{Robustness Tests}

Thus far, evidence has shown that international instability risk is a valid source of systematic risk. Differences in countries' exposure to this risk can help explain the cross-country return variations. One question still remains. Does international instability continue to provide explanatory power when other commonly used pricing factors are included? How does the contribution of international instability risk on international asset prices relate to other macroeconomic factors, such as GDP growth or changes in fiscal policy? We address these

external conflict, corruption, military in politics, religion in politics, law and order, ethnic tensions, democratic accountability, and bureaucracy equality.

${ }^{7}$ Average political risk ratings are calculated over the same sample period in which the exposure coefficient is estimated. Since ICRG data is only available to us until the year of 2012, all estimation periods end in 2012 . The correlations are (correlation, $t$-statistic): bureaucracy quality $(0.76,3.31)$, socioeconomic conditions $(0.60,4.89)$, corruption $(0.56,3.55)$, law and order $(0.54,2.56)$, military in politics $(0.52,1.89)$, internal conflict $(0.45,2.28)$, religion in politics $(0.44,1.89)$, democratic accountability $(0.42,1.76)$, external conflict $(0.34,1.20)$, ethnic tensions $(0.20,0.76)$, investment profile $(0.10,1.36)$, and government stability $(0.07,0.64)$. 
questions by assessing the pricing power of instability risk controlling for these alternative factors.

\section{World Market Risk}

We use the excess returns of the cum-dividend MSCI World Index over the U.S. T-bill rate to proxy the global market risk. Although the MSCI World Index is a developed market-based index, it is chosen to proxy for the worldwide market risk for two reasons. First, developed markets represent a large fraction of total global market capitalization. In addition, the World Index has longer coverage than the All Country World Index, which covers 44 countries of both developed and emerging markets, while the correlation of the two over 99\%. Column 2 of Table V indicates that while the global market risk is also important, instability risk continues to yield a significant price of risk. That is, in addition to the fraction of the risk premium explained by market risk, the instability risk also helps to explain the risk premium in the international stock market.

Insert Table V about here.

\section{Currency Risk}

Solnik (1974) argues that when purchasing power parity does not hold, investors face exchange rate risk for investing internationally. As a result, the exchange rate risk should be priced in international stock markets. In addition, since the MSCI country indices are quoted in U.S. dollars, returns are likely to incorporate the effect of exchange rate fluctuations. To control for the fluctuations in currency exchange rates, we include a dollar factor in our model. Following Verdelhan (2010), the dollar factor is defined as the equally-weighted average changes of the dollar exchange rates against other currencies. Section I of the appendix contains details regarding factor construction. We find that instability risk remains a valid pricing factor when the currency risk is 
controlled for (Column 3 of Table V). Tests using currency risk proxied by the Federal Reserve trade-weighted U.S. Dollar Index against seven major currencies also yield similar results.

\section{Global Economic Conditions}

Global economic conditions are likely to have a systematic impact on cross-country stock returns. Thus, we include the global GDP growth per capita as a control factor. Column 4 of Table $\mathrm{V}$ presents the market prices for both IIR and global GDP growth. The price of risk for IIR remains significant. In unreported results (available upon request), if we project the IIR factor on GDP growth, the orthogonalized residual continues to carry a significant risk premium. However, we do not want to understate the impact of world economic conditions on cross-country stock market performance. The price of risk on global GDP growth is positive and significant $\left(\lambda_{g d p}=3.72, t\right.$ statistic $=2.05)$ and the GDP growth displays significant pricing power $\left(\lambda_{g d p}=3.62, t\right.$-statistic $=$ 2.06) when it is used as the sole pricing factor.

\section{Impact of U.S. Militarization}

The importance of the U.S. in international militarization is not negligible. The U.S., on average, accounts for $34 \%$ of the world's total military expenditures and $27 \%$ of world's total GDP over the sample period from 1970-2014. Could it be the case that the risk premia associated with instability risk in fact compensates for changes in U.S. military expenditures? We find that this is not the case. When we include both the growth of U.S. militarization and IIR in the regression, IIR still has pricing power, but U.S. militarization growth does not (Column 5 of Table V). This suggests that the pricing power of IIR cannot be driven by the militarization of a single country, even one as powerful as the U.S. However, powerful states collectively could affect international instability. The instability factor calculated using the top 10 countries with the largest military 
expenditures has a correlation of over 0.95 with the IIR factor and exhibits a significant pricing power at a similar magnitude $\left(\lambda_{\text {mil10 }}=5.28, t\right.$-statistic $\left.=2.02\right) .{ }^{8}$

\section{Fiscal Policy Shock}

For many countries, military expenditures often account for a large proportion of fiscal expenditures. The U.S. defense budget accounts for about $19 \%$ of federally budgeted expenditures and $28 \%$ of estimated tax revenues in fiscal year 2013. Thus, could it be the case that our international instability factor actually captures global fiscal policy shocks? We control for fiscal shocks as measured by the growth rate of total government debt over total GDP. The estimated market prices for instability risk and global fiscal shock are presented in Column 6 of Table V. Both factors carry significant and negative prices of risk. This finding suggests that international instability risk is not the same as general fiscal shocks.

We also estimate the price of international instability risk when all potential alternatives discussed above are controlled for. The estimated price of risk remains statistically significant with a similar magnitude. While some other pricing factors also contribute, international instability is indeed a robust source of systematic risk that helps to explain the cross-sectional variation of international stock market returns.

\section{Expected vs. Unexpected Components of IIR}

We decompose the international instability risk factor into an expected component and an unexpected component using an AR(1) regression. We assess the pricing power of each component when all alternative risk factors are controlled for. Columns 8 and 9 of Table IV present the market prices of risk associated with the expected and the unexpected components, respectively. The

\footnotetext{
${ }^{8}$ The list of the top ten military spenders varies from year to year. However, countries included in the list more than 20 times are: the U.S. (45), China (45), France (45), the United Kingdom (45), Japan (45), Russia (43), Saudi Arabia (40), Italy (36), Germany (25), and Poland (20).
} 
pricing power of IIR is driven by the unexpected component. The unexpected component yields a negative and significant price of risk, while the expected component does not.

\section{Additional Results}

\section{A. Instability Risk Mimicking Portfolio}

To conduct tests with higher frequency data, we construct an instability risk mimicking portfolio (IMP). The portfolio space includes the six Fama-French (1993) global benchmark portfolios formed on size and book-to-market and the MSCI Emerging Markets Index portfolio. ${ }^{9}$ We project the international instability risk factor onto these seven portfolios following Equation (7) and estimate the weights $\hat{b}=[-1.33,1.47,-0.05,0.90,-0.36,0.17,0.19]$, where the weights $\hat{b}$ are normalized to one. The IMP is constructed as the fitted excess return as in Equation (8). The tradable IMP has a high correlation of $62 \%$ with the non-tradable instability factor. The sample period of IMP is from January 1991-January $2015 .^{10}$

$$
\begin{aligned}
& f_{t}^{g}=a+b^{\prime}[F F 6 F, E M]_{t}+\epsilon_{t} \\
& I M P_{t}=\hat{b}^{\prime}[F F 6 F, E M]_{t}
\end{aligned}
$$

First, we assess the time series pricing power of the IMP. The annualized mean average pricing error (MAPE) is $4.05 \%$ compared to the average total risk premium of $9.71 \%$ (Columns 1 and 2 of Panel A of Table VI). Next, we compare the MAPE using the IMP with the other models. These

\footnotetext{
${ }^{9}$ We also consider two alternative sets of spanning assets: 1) the MSCI Developed Markets Index portfolio and the MSCI Emerging Markets Index portfolio and 2) the MSCI Developed Markets Index portfolio, the MSCI Emerging Markets Index portfolio, and the Fama-French (1993) Global Momentum Portfolio. The results are similar and available upon request.

${ }^{10}$ The IMP shares the shortest common length of the spanning assets. The Fama-French (1993) global portfolios are available at monthly frequencies from January 1991-January 2015, while the excess returns of the MSCI Emerging Markets Index are available from January 1988-January 2015.
} 
include the market model, the Fama-French (1993) three-factor model, and the Fama-French threefactor plus momentum model. The MSCI Emerging Markets Index is also included as those factors are all constructed based on stocks from developed countries. We find that the IMP delivers a comparable MAPE relative to the other specifications. The Gibbons-Ross-Shanken (GRS) Fstatistic suggests that the hypothesis of pricing errors as jointly zero cannot be rejected. It is the only model in the list where the joint-zero hypothesis cannot be rejected. In addition, the IMP also exhibits reasonable pricing power in the cross-section. The annualized cross-sectional intercept for the IMP is $-1.64 \%$, which is slightly larger than the $1.43 \%$ for the market model, but considerably lower than the $2.04 \%$ for the Fama-French (1993) factors model and 3.40\% for the Fama-French plus momentum model (Panel B of Table VI). In summary, the results support our earlier finding that international political instability is a valid source of systematic risk that helps to explain the risk premia in international stock markets.

Insert Table VI about here.

\section{B. Alternative Measures of IIR}

We acknowledge that while our proposed IIR measure offers several important benefits as discussed in Section I.B, it could possibly be affected by changes in global GDP or changes in the USD exchange rate against other currencies. To assess whether these influences play a key role in our pricing results, we repeat our exercise using four alternative measures of IIR (Table VII).

Insert Table VII about here.

The first three alternative measures of international instability risk are constructed based on 
the original measure, but orthogonalized against the growth of GDP and the changes in dollar value. Specifically, we regress the IIR measure on the growth of world GDP per capita and a dollar factor that measures the changes in U.S. dollar value against several major currencies, each respectively (and then together), and use the residuals in the cross-country pricing tests. We find that the remaining component of IIR orthogonalized to the growth of GDP continues to carry a negative price of risk and explains the return differences of the 44 MSCI country indices. While both the magnitude and the statistical significance are slightly lower than the benchmark base, the price of risk remains significant at the $10 \%$ level. In addition, we also observe larger exposure for emerging countries relative to developed countries. The alternative measure of IIR orthogonalized to the changes in dollar value also yield similar results. Thus, similar results are found when IIR is orthogonal to both GDP growth and the dollar factor. The results using these three alternative measures provide us some confidence that changes in global GDP or changes in the U.S. dollar are unlikely to be the only pricing force of the proposed IIR.

We construct the fourth alternative measure for international instability risk by aggregating growth rates of military expenditures computed at the country level. Specifically, we first convert country-level military expenditures measured in current USD into real local currency using the corresponding exchange rates and inflation rates. We then compute the growth rate of real military expenditures per capita for each country and aggregate these growth rates into one global measure weighted by GDP. We find that international instability risk proxied by this alternative measure continues to explain the cross-section of international stock market returns. The price of risk is -2.90 with a $t$-statistic of -1.85 when all countries' indices are included in the Fama-MacBeth (1973) regressions. However, the statistical significance of the estimates is lower when only EMI and WI are used as test assets. 


\section{The Impact of the Financial Crisis}

We conduct cross-sectional pricing tests using a subsample excluding the 2007-2009 financial crisis to determine whether the recession is an influential event for the relation between IIR and stock returns (Table VIII). The price of risk for the IIR is still negative with a magnitude of -3.83 and a $t$-statistic of -1.64 when IIR is the only pricing factor. By repeating the exercise for subsamples excluding each of the three years sequentially, we find that the price of risk remains at a similar level with 5\% statistical significance for the subsamples excluding 2007 or 2008, and with $10 \%$ statistical significance for the subsample excluding 2008. If we include control variables as additional pricing factors, the price of risk estimated over the sample excluding 2007-2009 yields a price of risk of -5.29 with a $t$-statistic of -1.88 . The results are quite similar if we exclude each of the three crisis years sequentially. Overall, our results suggest that the drop in GDP during the 2007-2009 financial crisis is not the only source of IIR's cross-sectional pricing power for countries' stock returns.

Insert Table VIII about here.

\section{U.S. Evidence}

In Section III.D, we find that international instability risk does not stem from changes in U.S. military expenditures alone. In this section, we look at the question from another angle. Do investors treat international instability as a systematic risk factor when they invest in U.S. stock portfolios or is the cross-sectional variation of U.S. portfolios more likely to be driven by changes in U.S. militarization?

The test assets include the Fama-French (1993) 25 size and book-to-market sorted portfolios and 17 industry portfolios, where the data are downloaded from Kenneth French's data library. 
Column 1 of Table IX reports the second stage market price of the instability risk. The estimated price of risk for the global instability factor is positive, but insignificant $(t$-statistic $=1.52)$. This finding suggests that investors do not seem to view international instability as a source of systematic risk when investing in U.S. stock portfolios. This observation is consistent with our earlier results that IIR has relatively little impact on developed markets.

Insert Table IX about here.

Investors also care little about changes in U.S.' own militarization (i.e., the country's direct involvement in military expansion). When the growth rate of U.S. military expenditures to GDP ratio is used as the sole pricing factor, the price of risk on the U.S. militarization factor is positive, but rarely significant (Column 2 of Table IX). Additionally, when we employ control variables, the price of risk for U.S. militarization does not appear significant (Columns 3-6 of Table IX). ${ }^{11}$

\section{Conclusion}

In this paper, we examine whether international instability affects cross-country asset prices. Different from previous work that focuses on the market's ex-post reaction to political crises, we emphasize the instability risk associated with constantly evolving political tensions and international conflicts. We propose a proxy for international instability risk by exploiting a unique dataset of military expenditures and study its asset pricing implications.

We find that international political instability is a valid pricing factor for international stock markets. Our factor helps to explain the cross-country return differences, complementary to

\footnotetext{
${ }^{11}$ The three proxies of U.S. fiscal shocks include the growth rate of U.S. debt to the GDP ratio, the real excess returns of the top three military contractors relative to the market return (Fisher and Peters, 2010), and the real excess returns on the U.S. defense industry portfolio relative to the market return (Berndt et al., 2012).
} 
existing global asset pricing models. The higher returns of emerging markets could be attributed to their greater exposure to international political instability risk. Aggregate international instability risk seems to affect stock markets through the consumption channel and the local political environment channel. 


\section{Appendix}

\section{Additional Data Description}

Control variables in the robustness tests

- MSCI World Index. The excess return is computed as the gross return of the MSCI World Index over the one-month U.S. risk free rate. The sample period is from 1970-2013.

- Dollar Factor. Dollar Factor is defined as the equally-weighted average change in the exchange rates between USD and other currencies. The factor is constructed following Verdelhan (2010). Exchange rate data are from the Penn World Table. We match country names with countries in the MSCI Index list. The sample periods associated with hyperinflation are excluded including Brazil from 1967-1994, Mexico from 1970-1993, and Peru from 1988-1990. The sample period is from 1970-2013.

- World GDP Growth. World GDP Growth is defined as the growth rate of world GDP per capita. Data are from the World Bank Indicator measured in constant 2000 USD. The sample period is from 1970-2013.

- U.S. Militarization. U.S. Militarization is measured as the growth rate of U.S. military expenditures over GDP. Data are available from the U.S. Bureau of Economic Analysis. The sample period is from 1930-2013.

- Global Debt/GDP. Global Debt/GDP is defined as the growth rate of the ratio between the total amount of government debt and the total GDP. Data are from two sources. The first one is the dataset provided by Jaimovich and Panizza (2010). This dataset covers the period from 19702005. The number of countries in the dataset varies from 27 in 1970 to 116 in 2005 . The global debt to GDP ratio in year $t$ is approximated by the sum of government debt divided by the sum of GDP, where both summations are taken over countries available in the dataset in that year. The second source is the global debt clock, available from The Economist's website, which covers the period from 2006-2013. The sample period for is from 1970-2013.

- US Debt/GDP. U.S. Debt/GDP is defined as the growth rate of U.S. public debt over GDP. Data come from Treasury Direct covering the nominal level of total U.S. public debt from 1790-2012. Data on GDP are from the U.S. Bureau of Economic Analysis. Note that while GDP is measured at the end of the calendar year, debt levels are measured as of the 30th of June each year until 1976 then changed to the 30th of September from 1977. To match the two datasets, we calculate the debt level at the end of each calendar year by applying linear interpolation. The sample period is from 1930-2013.

- VIX. VIX is measured as the annual average of the VIX uncertainty measure calculated using daily observations within each calendar year. The data is available from the Chicago Board Options Exchange. The sample period is from 1990-2013.

- US Mil Contractor. U.S. Mil Contractor denotes the average real excess return of the top three military contractors over the market return. We follow Fisher and Peters (2010) to determine 
the list of top three contractors, and compute the return of a value-weighted portfolio. The sample period is from 1958-2013.

- Guns. Guns denotes the excess return of the defense stocks over the market return computed following Berndt et al. (2012). Defense stocks are identified as firms that fit into Fama-French's (1993) definition of the "Guns" industry in their 49 industry portfolios. The sample period is from 1964-2013.

Channel Variables

- Consumption (MI). Consumption (MI) denotes the unexpected consumption growth for middle income countries. Consumption growth is computed using data on real consumption per capita from the World Bank Databank. Unexpected consumption growth is measured as the residuals from an AR(1) regression. The sample period is from 1971-2013.

- Consumption (OECD). Consumption (OECD) denotes unexpected consumption growth for the high income OECD countries. Consumption growth is computed using data on real consumption per capita from the World Bank Databank. The unexpected consumption growth is measured as the residuals from an $\mathrm{AR}(1)$ regression. The sample period is from 1971-2013.

- Magnitude of Wars. The magnitude of wars is measured by the number of deaths occurring in inter-state and extra-state wars. The Correlates of War Database is the source for our data on deaths caused by wars. To calculate the total number of deaths in a given year, we first calculate the duration (in terms of months) of each war and obtain a measurement of the number of deaths per war per month. We then total the number of deaths across months to determine the total number of deaths in a given year. The sample period is from 1970-2007.

Excess Returns Used in the Time Series Analysis of the IMP

- $\quad C A P M^{G}$. The excess return of the Fama-French (1993) global market factor. The sample period is from January 1991-January 2015.

- $F F^{G}$. The returns of three Fama-French (1993) global factors (market, size, and book-tomarket). The sample period is from January 1991-January 2015.

- $M M T^{G}$. The excess return of the global winner minus the loser momentum portfolio. The sample period is from November 1990-January 2015.

- $F F^{G}$ 6. The excess returns of six Fama-French (1993) global benchmark portfolios formed on size and book-to-market. The sample period is from November 1990-January 2015. 


\section{GMM Estimates with Efficient Weighting Matrix}

In the GMM tests, two assets are used as test assets, the MSCI Emerging Market Index and the MSCI World Index. Thus, we have five moment conditions and four coefficients to estimate. Following Lynch and Wachter (2013), we partition the moment conditions into two sets: 1) one set depends only on data available for the full period and 2) the other set depends on both full period and partial period data. The moment conditions and data we consider are given below:

$E\left[f\left(x_{t} ; \theta\right)\right]=E\left[\begin{array}{l}f_{1}\left(x_{1 t} ; \theta\right) \\ f_{2}\left(x_{2 t} ; \theta\right)\end{array}\right]=0$

$f_{1}\left(x_{1 t} ; \theta\right)=\left[\begin{array}{c}R_{D, t}-\beta_{D}\left(\lambda-\mu+f_{t}\right) \\ \left(R_{D, t}-\beta_{D}\left(\lambda-\mu+f_{t}\right)\right) f_{t} \\ \mu-f_{t}\end{array}\right]$

$f_{2}\left(x_{1 t} ; \theta\right)=\left[\begin{array}{c}R_{E, t}-\beta_{E}\left(\lambda-\mu+f_{t}\right) \\ \left(R_{E, t}-\beta_{E}\left(\lambda-\mu+f_{t}\right)\right) f_{t}\end{array}\right]$

$x=\left(R_{D, t}, f_{t} ; R_{E, t}\right)=\left(x_{1 t} ; x_{2 t}\right),\left\{\begin{array}{lc}x_{1 t}, & t=1, \cdots, T \\ x_{2 t}, & t=(1-\bar{\lambda}) T+1, \cdots, T\end{array}\right.$

where $\bar{\lambda}$ is the fraction of the period that all data is available, and $\theta=\left(\beta_{D}, \beta_{E}, \lambda, \mu\right)^{\prime}$.

As in Lynch and Wachter (2013), we employ the following sample moment conditions: 
$g_{1, T}(\theta)=\frac{1}{T}\left(\begin{array}{c}\sum_{t=1}^{T} R_{D, t}-\beta_{D}\left(\lambda-\mu+f_{t}\right) \\ \sum_{t=1}^{T}\left(R_{D, t}-\beta_{D}\left(\lambda-\mu+f_{t}\right)\right) f_{t} \\ \sum_{t=1}^{T} \mu-f_{t}\end{array}\right)$

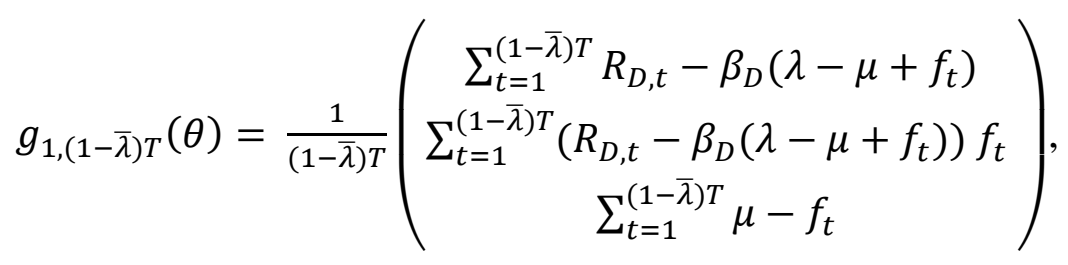

$g_{1, \bar{\lambda} T}(\theta)=\frac{1}{\bar{\lambda} T}\left(\begin{array}{c}\sum_{t=(1-\bar{\lambda}) T+1}^{T} R_{D, t}-\beta_{D}\left(\lambda-\mu+f_{t}\right) \\ \sum_{t=(1-\bar{\lambda}) T+1}^{T}\left(R_{D, t}-\beta_{D}\left(\lambda-\mu+f_{t}\right)\right) f_{t} \\ \sum_{t=(1-\bar{\lambda}) T+1}^{T} \mu-f_{t}\end{array}\right)$,

$g_{2, \bar{\lambda} T}(\theta)=\frac{1}{\bar{\lambda} T}\left(\begin{array}{c}\sum_{t=(1-\bar{\lambda}) T+1}^{T} R_{E, t}-\beta_{E}\left(\lambda-\mu+f_{t}\right) \\ \sum_{t=(1-\bar{\lambda}) T+1}^{T}\left(R_{E, t}-\beta_{E}\left(\lambda-\mu+f_{t}\right)\right) f_{t}\end{array}\right)$.

Suppose the variance-covariance matrix for the moment condition $\left(f_{1}\left(x_{1 t} ; \theta\right) ; f_{2}\left(x_{t} ; \theta\right)\right)$ is defined as $S=\left(\begin{array}{ll}S_{11} & S_{12} \\ S_{21} & S_{22}\end{array}\right)$, and $S_{11}$ is the variance-covariance matrix that only uses the data from the full period. We use $S_{11}=\sum_{\tau=-\infty}^{\infty} \gamma_{11}(-\tau)=\sum_{\tau=-\infty}^{\infty} E\left[f_{1} f_{1-\tau}^{\prime}\right]$ that is the same as the standard GMM variance-covariance matrix.

To estimate $\widehat{S}$, we need to have some initial parameter value $\widehat{\theta}$. We use the parameter estimated from a long estimator given by the following definition:

$\widehat{\theta_{T}^{L}}=\operatorname{argmin}_{\theta}\left[g_{1, t}(\theta)^{\prime} g_{2, \bar{\lambda} T}(\theta)^{\prime}\right]\left(I_{T}\right)\left[\begin{array}{c}g_{1, T}(\theta) \\ g_{2, \lambda T}(\theta)\end{array}\right]$, 
where we choose the identity matrix as the weighting matrix. We employ $\widehat{S_{11}}=T \sum_{\tau=-\infty}^{\infty} g_{1, t}\left(\widehat{\theta_{T}^{L}}\right) g_{1, t}\left(\widehat{\theta_{T}^{L}}\right)^{\prime}$, which is a three-by-three matrix.

To estimate the other parts of the variance-covariance matrix, we follow Stambaugh's (1997) procedure that makes use of the full sample. For $t=(1-\bar{\lambda}) T+1, \cdots, T$, we run the following two regressions that regress the moment condition $f_{2}\left(x_{t} ; \widehat{\theta_{T}^{L}}\right)$ on the moment condition $f_{1}\left(x_{1 t} ; \widehat{\theta_{T}^{L}}\right)$ :

$\left\{\begin{array}{l}f_{2, t}^{1}=\alpha_{1}+\beta^{11} f_{1, t}^{1}+\beta^{12} f_{1, t}^{2}+\beta^{13} f_{1, t}^{3}+\epsilon_{t}^{1} \\ f_{2, t}^{2}=\alpha_{2}+\beta^{21} f_{1, t}^{1}+\beta^{22} f_{1, t}^{2}+\beta^{23} f_{1, t}^{3}+\epsilon_{t}^{2}\end{array}\right.$,

we can employ $\hat{B}=\left(\begin{array}{lll}\widehat{\beta^{11}} & \widehat{\beta^{12}} & \widehat{\beta^{13}} \\ \widehat{\beta^{21}} & \widehat{\beta^{22}} & \widehat{\beta^{23}}\end{array}\right)$ and $\widehat{\Sigma}=\widehat{E}\left[\begin{array}{cc}\epsilon_{t}^{1} \epsilon_{t}^{1} & \epsilon_{t}^{1} \epsilon_{t}^{2} \\ \epsilon_{t}^{2} \epsilon_{t}^{1} & \epsilon_{t}^{2} \epsilon_{t}^{2}\end{array}\right]$, and then we can obtain the variance covariance matrix estimated using the full sample:

$\hat{S}=\left(\begin{array}{ll}\widehat{S_{11}} & \widehat{S_{12}} \\ \widehat{S_{21}} & \widehat{S_{22}}\end{array}\right)=\left(\begin{array}{cc}\widehat{S_{11}} & \widehat{S_{12}} \hat{B}^{\prime} \\ \hat{B}^{\prime} \widehat{S_{21}} & \hat{\Sigma}+\widehat{B}^{\prime} \widehat{S_{22}} \hat{B}^{\prime}\end{array}\right)$.

Now, we are ready to define the adjusted estimator: $\widehat{\theta_{T}^{A}}=\operatorname{argmin} g_{T}^{A \prime}\left(\widehat{S^{A}}\right)^{-1} g_{T}^{A}$,

where $g_{T}^{A}=\left(\begin{array}{l}g_{1, t}(\theta) \\ g_{2, t}^{A}(\theta)\end{array}\right), g_{2, t}^{A}(\theta)=g_{2, \bar{\lambda} T}(\theta)+\hat{B}\left(g_{1, t}(\theta)-g_{1, \bar{\lambda} T}(\theta)\right)$, and

$\hat{S}^{A}=\left(\begin{array}{cc}\bar{\lambda} \widehat{S_{11}} & \bar{\lambda} \widehat{S_{12}} \\ \bar{\lambda} \widehat{S_{21}} & \widehat{S_{22}}-(1-\bar{\lambda}) \widehat{S_{21}} \widehat{S_{11}} \widehat{S_{12}}\end{array}\right)$. 
Finally, we determine the asymptotic distribution of our adjusted estimator:

$\sqrt[T]{\widehat{\theta_{T}^{A}}-\theta_{0}} \stackrel{d}{\rightarrow} N\left(0,\left(D^{\prime}\left(S^{A}\right)^{-1} D\right)^{-1}\right)$

where $D=\left[\begin{array}{cccc}\lambda & 0 & \beta^{D} & -\beta^{D} \\ \lambda \mu+\operatorname{var}(f) & 0 & \beta^{D} \mu & \beta^{D} \mu \\ 0 & 0 & 0 & 1 \\ 0 & \lambda & \beta^{D} & -\beta^{E} \\ 0 & \lambda \mu+\operatorname{var}(f) & \beta^{E} \mu & -\beta^{E} \mu\end{array}\right]$. 


\section{Table A1. Cross-Country Evidence of International Instability Risk}

This table presents markets' exposure to international instability risk (IIR) and the associated price of risk estimated using the FamaMacBeth (1973) two-pass regressions. Test assets are the excess returns of the 42 MSCI country indices (excluding Poland and Turkey). Panel A reports countries' factor loadings on IIR from time series regressions: $R_{i, t}^{e}=\alpha_{i}+\beta_{i} I I R_{t}+\epsilon_{i, t}$. Panel B provides the market price of IIR from cross-sectional regressions: $R_{i, t}^{e}=\lambda_{0, t}+\lambda_{t} \beta_{i}+\eta_{i, t}, \bar{\lambda}=\frac{1}{T} \sum_{t=1}^{T} \lambda_{t}$. Newey-West (1987) three-lag adjusted $t$-statistics are reported in parentheses. The sample period is from 1970-2013.

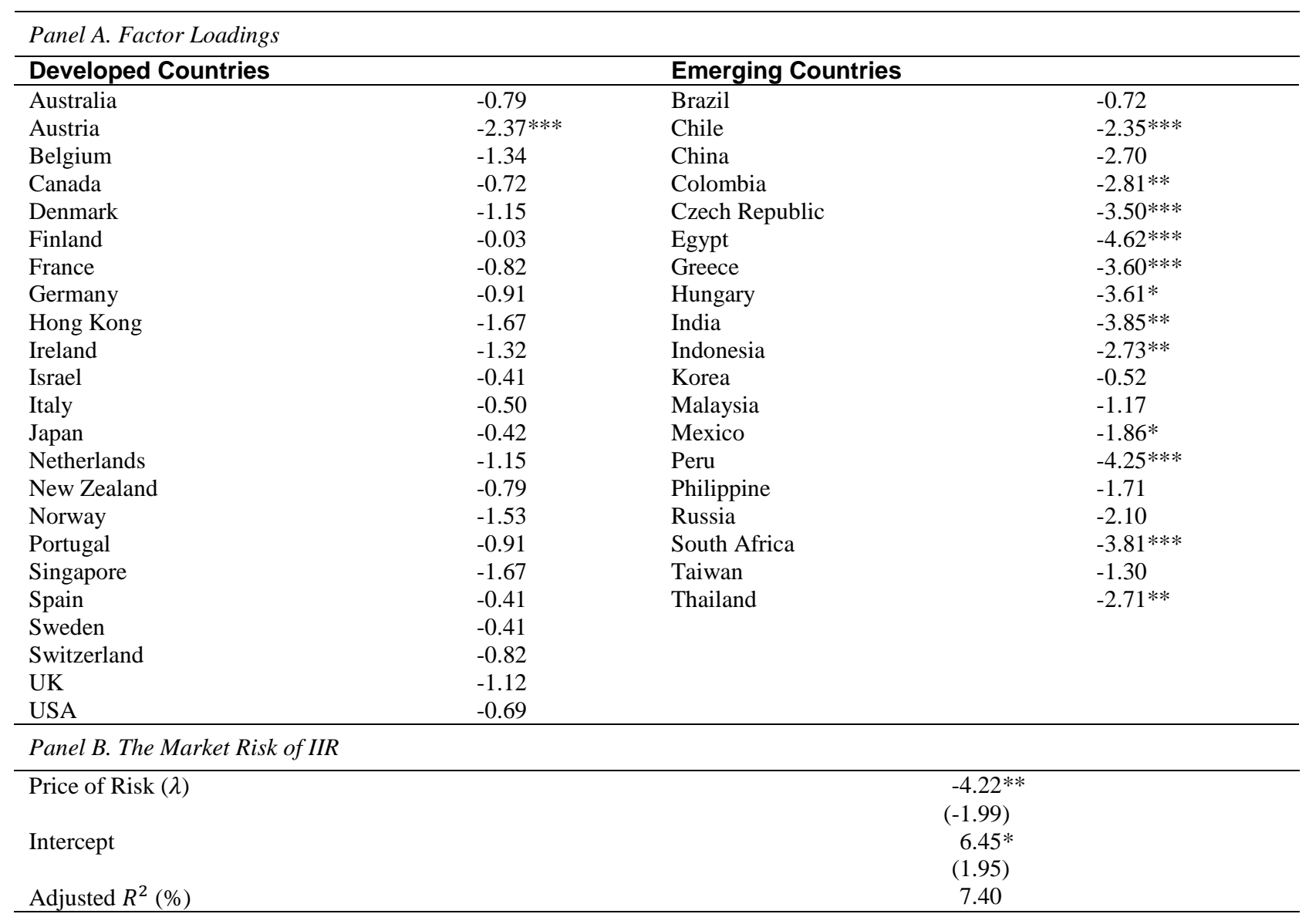

\footnotetext{
*** Significant at the 0.01 level.

** Significant at the 0.05 level.

* Significant at the 0.10 level.
} 


\section{References}

Baker, S., N. Bloom, and S. Davis, 2016, "Measuring Economic Policy Uncertainty," The Quarterly Journal of Economics 131(4), 1593-1636.

Bansal, R. and A. Yaron, 2004, "Risks for the Long Run: A Potential Resolution of Asset Pricing Puzzles," Journal of Finance 59(4), 1481-1509.

Barro, R., 2006, “Rare Disasters and Asset Markets in the Twentieth Century,” The Quarterly Journal of Economics 121(3), 823-866.

Bekaert, G., C. Harvey, C. Lundblad, and S. Siegel, 2014, "Political Risk Spreads," Journal of International Business Studies 45(4), 471-493.

Belo, F., V.D. Gala, and J. Li, 2013, “Government Spending, Political Cycles, and the Cross Section of Stock Returns," Journal of Financial Economics 107(2), 305-324.

Belo, F. and J. Yu, 2013, “Government Investment and the Stock Market," Journal of Monetary Economics 60(3), 325-339.

Berkman, H., B. Jacobsen, and J.B. Lee, 2011, "Time-Varying Rare Disaster Risk and Stock Returns," Journal of Financial Economics 101(2), 313-332.

Berndt, A., H. Lustig, and S. Yeltekin, 2012, "How does the U.S. Government Finance Fiscal Shocks?" 
American Economic Journal: Macroeconomics 4(1), 69-104.

Bittlingmayer, G., 1998, “Output, Stock Volatility, and Political Uncertainty in a Natural Experiment: Germany, 1880-1940,” Journal of Finance 53(6), 2243-2257.

Boutchkova, M., H. Doshi, A. Durnev, and A. Molchanov, 2012, "Precarious Politics and Return Volatility," Review of Financial Studies 25(4), 1111-1154.

Breeden, D., 1979, “An Intertemporal Asset Pricing Model with Stochastic Consumption and Investment Opportunities," Journal of Financial Economics 7(3), 265-296.

Brogaard, J. and A. Detzel, 2015, "The Asset-Pricing Implications of Government Economic Policy Uncertainty," Management Science 61(1), 3-18.

Burnside, C., M. Eichenbaum, and J. Fisher, 2004, "Fiscal Shocks and Their Consequences," Journal of Economic Theory 115(1), 89-117.

Campbell, J., 1999, “Asset Prices, Consumption, and the Business Cycle," Handbook of Macroeconomics 1, 1231-1303.

Campbell, J.Y., 2003, "Consumption-Based Asset Pricing," Handbook of the Economics of Finance 1, 803-887.

Chassang, S. and G.P.I. Miquel, 2010, "Conflict and Deterrence Under Strategic Risk,” The Quarterly 
Journal of Economics 125(4), 1821-1858.

Croce, M.M., H. Kung, T.T. Nguyen, and L. Schmid, 2012, "Fiscal Policies and Asset Prices," Review of Financial Studies 25(9), 2635-2672.

Croce, M. T. Nguyen, and L. Schmid, 2012, "The Market Price of Fiscal Uncertainty," Journal of Monetary Economics 59(5), 401-416.

Cumby, R. and J. Glen, "Evaluating the Performance of International Mutual Funds," Journal of Finance 45(2), 497-521, 199.

Dumas, B. and B. Solnik, 1995, "The World Price of Foreign Exchange Risk," Journal of Finance 50(2), 445-479.

Durnev, A., 2010, “The Real Effects of Political Uncertainty: Elections and Investment Sensitivity to Stock Prices, University of Iowa Working Paper.

Erb, C., C. Harvey, and T. Viskanta, 1996, "Political Risk, Economic Risk, and Financial Risk," Financial Analysts Journal 52(6), 29-46.

Fama, E. and K. French, 1993, "Common Risk Factors in the Returns on Stocks and Bonds," Journal of Financial Economics 33, 3-56.

Fama, E. and J. MacBeth, 1973, "Risk, Return, and Equilibrium: Empirical Tests," The Journal of 
Political Economy 81(3), 607-636.

Fearon, J., 1997, "Signaling Foreign Policy Interests Tying Hands versus Sinking Costs," Journal of Conflict Resolution 41(1), 68-90.

Ferson, W. and C. Harvey, 1993, "The Risk and Predictability of International Equity Returns," Review of Financial Studies 6(3), 527-566.

Ferson, W. and C. Harvey, 1994, "Sources of Risk and Expected Returns in Global Equity Markets," Journal of Banking \& Finance 18(4), 775-803.

Fisher, J. and R. Peters, 2010, "Using Stock Returns to Identify Government Spending Shocks," The Economic Journal 120(544), 414-436.

Frey, B. and M. Kucher, 2000, "History as Reflected in Capital Markets: The Case of World War II," The Journal of Economic History 60(2), 468-496.

Frey, B. and M. Kucher, 2001, "Wars and Markets: How Bond Values Reflect the Second World War," Economica 68(271), 317-333.

Gabaix, X., 2012, "Variable Rare Disasters: An Exactly Solved Framework for Ten Puzzles in MacroFinance," The Quarterly Journal of Economics 127(2), 645-700.

Gao, P. and Y. Qi, 2013, "Political Uncertainty and Public Financing Costs," University of Notre 
Dame Working Paper.

Gibbons, M., S. Ross, and J. Shanken, 1989, "A Test of the Efficiency of a Given Portfolio," Econometrica 57(5), 1121-1152.

Gomes, F., A. Michaelides, and V. Polkovnichenko, 2013, "Fiscal Policy and Asset Prices with Incomplete Markets,” Review of Financial Studies 26(2), 531-566.

Gourio, F., 2012, "Disaster Risk and Business Cycles,” The American Economic Review 102(6), 27342766.

Harvey, C., 1991, “The World Price of Covariance Risk,” Journal of Finance 46(1), 111-157.

Jackson, M., 2009, “Networks and Economic Behavior,” Annual Review of Economics 1, 489-511.

Jackson, M. and M. Morelli, 2011, “The Reasons for Wars: An Updated Survey,” The Handbook on the Political Economy of War, 34-57.

Jagannathan, R. and Z. Wang, 2002, "Empirical Evaluation of Asset-Pricing Models: A Comparison of the SDF and Beta Methods," Journal of Finance 57(5), 2337-2367.

Jaimovich, D. and U. Panizza, 2010, "Public Debt Around the World: A New Data Set of Center Government Debt," Applied Economics Letters 77(1), 19-24. 
Julio, B. and Y. Yook, 2012, "Political Uncertainty and Corporate Investment Cycles," Journal of Finance 67(1), 45-83.

Leigh, A., J. Wolfers, and E. Zitzewitz, 2003, "What Do Financial Markets Think of War in Iraq?" NBER Working Paper.

Lewellen, J., S. Nagel, and J. Shanken, 2010, “A Skeptical Appraisal of Asset Pricing Tests,” Journal of Financial Economics 96, 175-194.

Lucas, Jr., R., 1978, “Asset Prices in an Exchange Economy,” Econometrica 46(6), 1429-1445.

Lynch, A. and J. Wachter, 2013, "Using Samples of Unequal Length in Generalized Method of Moments Estimation,” Journal of Financial and Quantitative Analysis 48(01), 277-307.

Mehra, R. and E. Prescott, 1985, “The Equity Premium: A Puzzle,” Journal of Monetary Economics $15(2), 145-161$

Newey, W. and K. West, 1987, “A Simple, Positive Semi-Definite, Heteroskedasticity and Autocorrelation Consistent Covariance Matrix, Econometrica 55(3), 703-708.

Pantzalis, C., D. Stangeland, and H. Turtle, 2000, "Political Elections and the Resolution of Uncertainty: The International Evidence,” Journal of Banking \& Finance 24(10), 1575-1604.

Pastor, L. and P. Veronesi, 2012, “Uncertainty About Government Policy and Stock Prices,” Journal 
of Finance 67(4), 1219-1264.

Pastor, L. and P. Veronesi, 2013, "Political Uncertainty and Risk Premia," Journal of Financial Economics 110(3), 520-545.

Ramey, V. and M. Shapiro, 1998, "Costly Capital Reallocation and the Effects of Government Spending," Carnegie-Rochester Conference Series on Public Policy 48(1), 145-194.

Rietz, T., 1988, “The Equity Risk Premium: A Solution,” Journal of Monetary Economics 22(1), 117131.

Savov, A., 2011, “Asset Pricing with Garbage,” Journal of Finance 66(1), 177-201.

Sialm, C., 2009, “Tax Changes and Asset Pricing,” American Economic Review 99(4), 1356-1383.

Solnik, B., 1974, “An Equilibrium Model of the International Capital Market,” Journal of Economic Theory 8(4), 500-524.

Stambaugh, R., 1997, “Analyzing Investments Whose Histories Differ in Length,” Journal of Financial Economics 45(3), 285-331.

Verdelhan, A., 2010, “A Habit-Based Explanation of the Exchange Rate Risk Premium,” Journal of Finance 65(1), 123-146. 
Wachter, J., 2013, “Can Time-Varying Risk of Rare Disasters Explain Aggregate Stock Market Volatility?" Journal of Finance 68(3), 987-1035.

Willard, K., T. Guinnane, and H. Rosen, 1996, "Turning Points in the Civil War: Views from the Greenback Market,” American Economic Review 86(4), 1001-1018.

Yogo, M., 2006, “A Consumption-Based Explanation of Expected Stock Returns,” Journal of Finance 61(2), 539-580.

Zussman, A., N. Zussman, and M.Ø. Nielsen, 2008, “Asset Market Perspectives on the IsraeliPalestinian Conflict,” Economica 75(297), 84-115. 
Figure I. Time Series of the International Instability Risk Factor and Aggregate Stock Index Returns

This figure plots the time series of the international instability risk factor (IIR) measured by the growth rate of global military expenditures scaled by GDP, as well as the excess returns of two aggregate MSCI stock indices: the MSCI Emerging Markets Index (EMI) for emerging markets and the MSCI World Index (WI) for developed markets. All series are demeaned. The sample period is from 1970-2013.

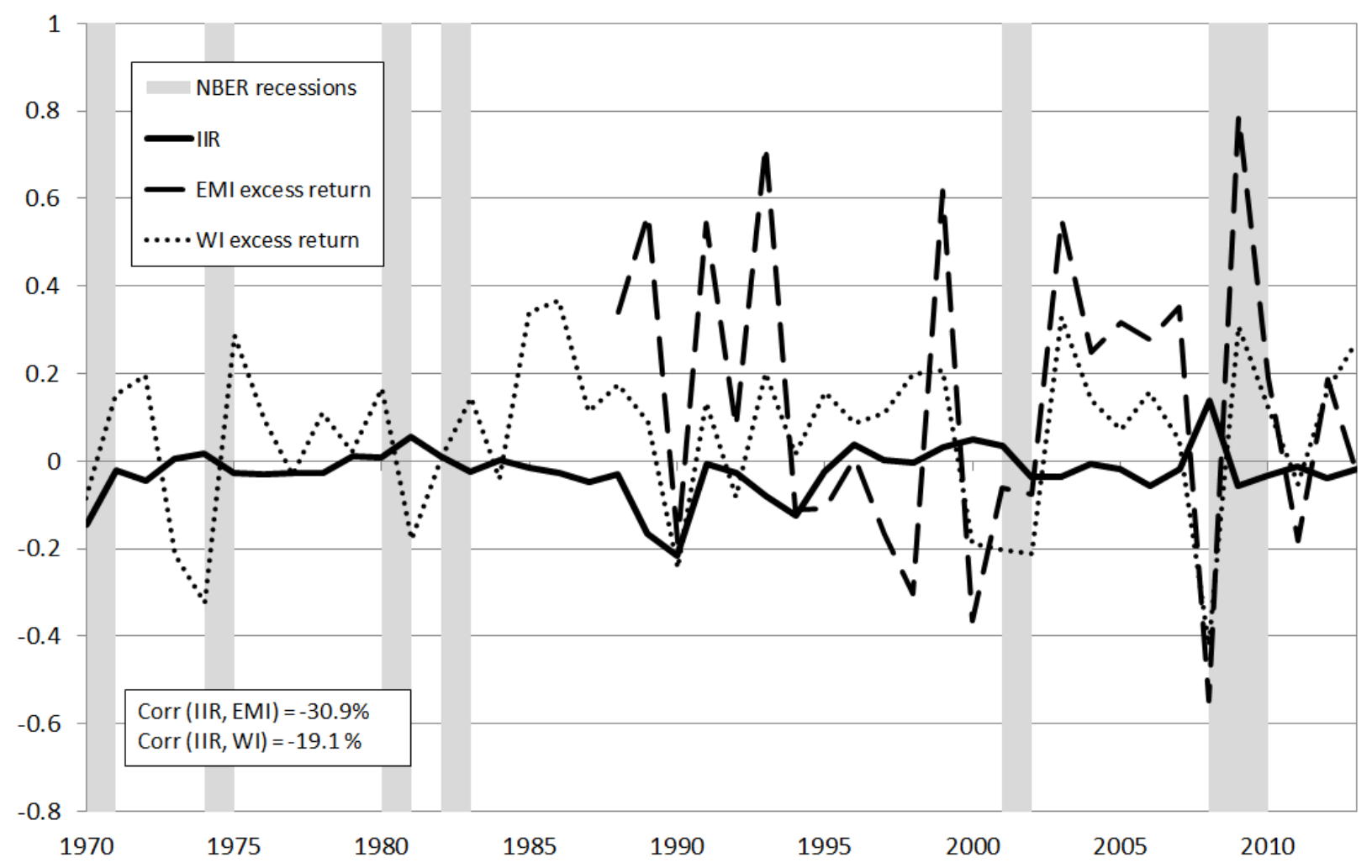




\section{Figure II. Countries' Exposures to International Instability Risk}

This figure plots 44 countries' average realized excess returns $\left(\frac{1}{T} \sum_{t=1}^{T} R_{i, t}^{e}\right)$ against their exposure to international instability risk. The solid dots represent countries with significant exposure (10\% significance level), while the empty dots represent countries with insignificant exposure.

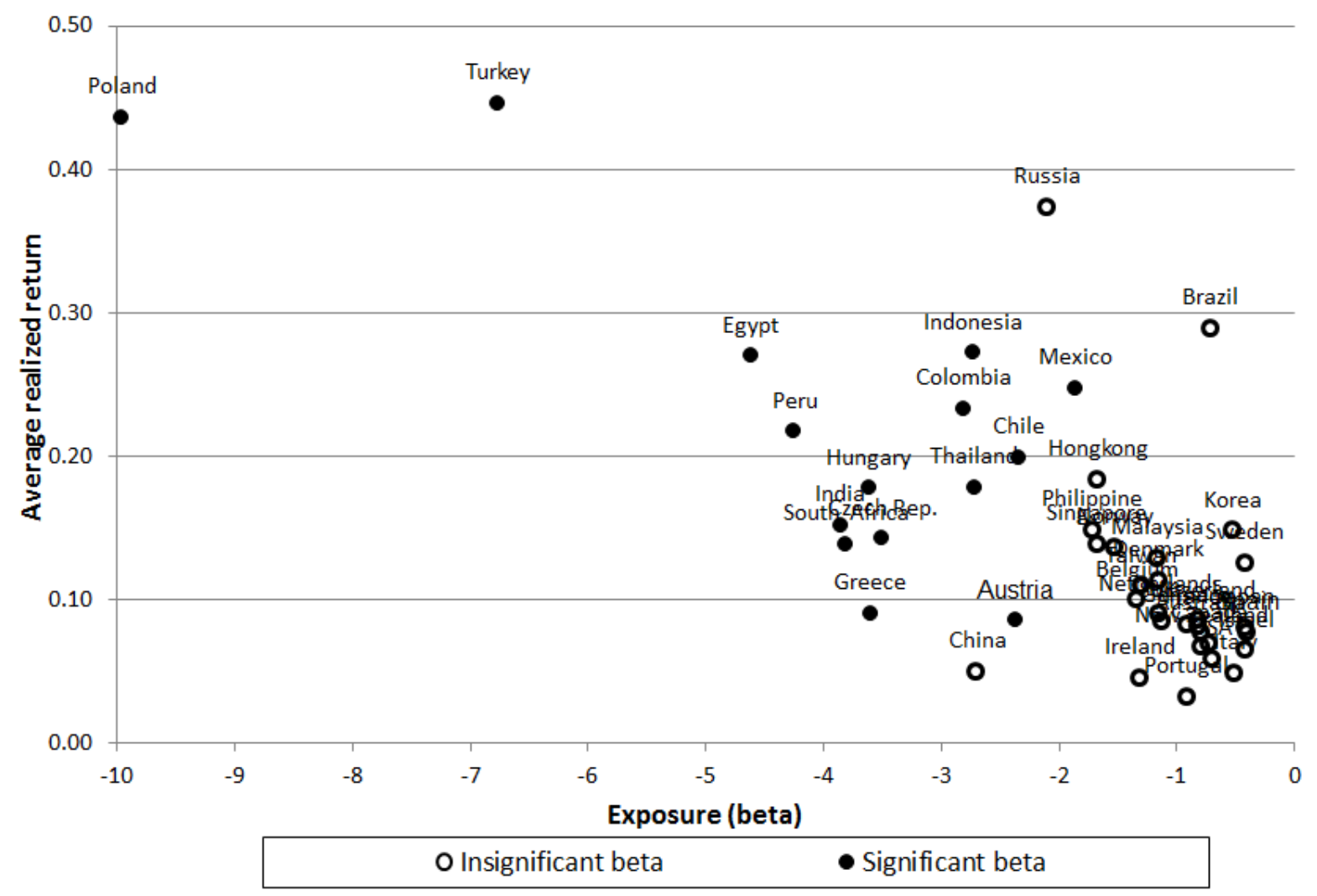




\section{Table I. International Stock Market Returns}

This table presents descriptive statistics of international equity market excess returns. The excess returns are calculated using the MSCI country index returns (cum-dividends) net of one-month U.S. risk-free rates. We present the mean, standard deviation, sample size, and sample coverage for 44 country indices, as well as two aggregate indices: the MSCI World Index for the developed markets and the Emerging Markets Index for emerging countries.

\begin{tabular}{|c|c|c|c|c|}
\hline Country & Mean (\%) & $\begin{array}{c}\text { Standard Deviation } \\
(\%)\end{array}$ & $\begin{array}{c}\text { No. of } \\
\text { Observations }\end{array}$ & Sample \\
\hline \multicolumn{5}{|l|}{ Developed Countries } \\
\hline Australia & 7.58 & 27.34 & 44 & $1970-2013$ \\
\hline Austria & 8.67 & 37.80 & 44 & $1970-2013$ \\
\hline Belgium & 10.37 & 28.43 & 44 & $1970-2013$ \\
\hline Canada & 6.94 & 22.06 & 44 & $1970-2013$ \\
\hline Denmark & 11.64 & 28.85 & 44 & $1970-2013$ \\
\hline Finland & 14.19 & 47.64 & 26 & $1988-2013$ \\
\hline France & 8.53 & 28.01 & 44 & $1970-2013$ \\
\hline Germany & 8.74 & 29.94 & 44 & $1970-2013$ \\
\hline Hong Kong & 18.15 & 45.58 & 44 & $1970-2013$ \\
\hline Ireland & 5.97 & 28.85 & 26 & $1988-2013$ \\
\hline Israel & 6.71 & 29.62 & 21 & $1993-2013$ \\
\hline Italy & 5.22 & 35.16 & 44 & $1970-2013$ \\
\hline Japan & 8.51 & 33.15 & 44 & $1970-2013$ \\
\hline Netherlands & 9.47 & 21.31 & 44 & $1970-2013$ \\
\hline New Zealand & 6.92 & 29.13 & 26 & $1988-2013$ \\
\hline Norway & 13.55 & 44.22 & 44 & $1970-2013$ \\
\hline Portugal & 3.58 & 28.09 & 26 & $1988-2013$ \\
\hline Singapore & 13.54 & 46.45 & 44 & $1970-2013$ \\
\hline Spain & 8.26 & 31.41 & 44 & $1970-2013$ \\
\hline Sweden & 12.81 & 29.73 & 44 & $1970-2013$ \\
\hline Switzerland & 8.96 & 24.34 & 44 & $1970-2013$ \\
\hline UK & 8.79 & 28.04 & 44 & $1970-2013$ \\
\hline USA & 6.46 & 18.10 & 44 & $1970-2013$ \\
\hline \multicolumn{5}{|l|}{ Emerging Countries } \\
\hline Brazil & 27.18 & 59.47 & 26 & $1988-2013$ \\
\hline Chile & 18.30 & 37.91 & 26 & $1988-2013$ \\
\hline China & 4.93 & 42.17 & 21 & $1993-2013$ \\
\hline Colombia & 21.16 & 47.52 & 21 & 1993-2013 \\
\hline Czech Rep. & 13.06 & 33.82 & 19 & $1995-2013$ \\
\hline Egypt & 25.98 & 59.88 & 19 & $1995-2013$ \\
\hline Greece & 10.73 & 44.66 & 26 & $1988-2013$ \\
\hline Hungary & 16.50 & 46.22 & 19 & $1995-2013$ \\
\hline India & 14.23 & 44.07 & 21 & $1993-2013$ \\
\hline Indonesia & 25.27 & 71.04 & 26 & $1988-2013$ \\
\hline Korea & 14.38 & 48.81 & 26 & $1988-2013$ \\
\hline Malaysia & 12.69 & 40.17 & 26 & $1988-2013$ \\
\hline Mexico & 23.75 & 41.71 & 26 & $1988-2013$ \\
\hline Peru & 19.25 & 39.99 & 21 & $1993-2013$ \\
\hline Philippine & 14.17 & 45.44 & 26 & $1988-2013$ \\
\hline Poland & 41.69 & 166.06 & 21 & $1993-2013$ \\
\hline Russia & 35.42 & 79.03 & 19 & $1995-2013$ \\
\hline South Africa & 12.94 & 31.78 & 21 & 1993-2013 \\
\hline Taiwan & 10.91 & 43.94 & 26 & $1988-2013$ \\
\hline Thailand & 16.58 & 52.35 & 26 & $1988-2013$ \\
\hline Turkey & 41.89 & 131.43 & 26 & $1988-2013$ \\
\hline \multicolumn{5}{|l|}{ Aggregate Indices } \\
\hline World Index & 6.18 & 18.45 & 44 & $1970-2013$ \\
\hline Emerging Markets Index & 14.05 & 35.43 & 26 & $1988-2013$ \\
\hline
\end{tabular}




\section{Table II. Notation and Summary Statistics}

This table presents the definitions of notations used in the construction of the international instability risk proxy (IIR) (Panel A), the descriptive statistics of IIR (Panel B), and the correlations between IIR and a list of economic and financial variables (Panel C). IIR is defined as the growth of global military expenditures scaled by global GDP. The economic and financial variables include: DMI, the excess returns of the MSCI World Index, EMI, the excess returns of the MSCI Emerging Markets Index, global GDP growth, the growth of global GDP per capita, dollar currency risk, the equally-weighted average change in the exchange rates between USD and other currencies, global debt/GDP, the growth of global debt over GDP ratio, and VIX, the average of daily VIX within each year.

Panel A. Notations

\begin{tabular}{ll}
\hline Mil $_{i t}$ & Military expenditure of country $i$ in year $t$ measured in current USD. \\
$G D P_{i t}$ & Gross domestic production of country $i$ in year $t$ measured in current USD. \\
$M i l G D P_{t}$ & Worldwide total military expenditures as a percentage of total GDP in year $t$, i.e., $\frac{\sum_{i} M i l_{i t}}{\sum_{i} G D P_{i t}}$. \\
$I I R_{t}$ & The growth of global military expenditures scaled by GDP, i.e., MilGDP $P_{t+1} / M i l G D P_{t}$.
\end{tabular}

\begin{tabular}{|c|c|c|}
\hline \multicolumn{3}{|c|}{ Panel B. Summary Statistics } \\
\hline \multicolumn{3}{|c|}{ IIR } \\
\hline Mean & \multicolumn{2}{|c|}{-0.023} \\
\hline Standard Deviation & \multicolumn{2}{|c|}{0.058} \\
\hline AR(1) Coefficient & \multicolumn{2}{|c|}{0.319} \\
\hline No. of Observations & \multicolumn{2}{|c|}{44} \\
\hline Sample Period & \multicolumn{2}{|c|}{$1970-2013$} \\
\hline \multicolumn{3}{|c|}{ Panel C. Correlations with Economic and Financial Variables } \\
\hline Variable & Correlation with IIR & Sample Period \\
\hline DM Excess Return & -30.91 & $1970-2013$ \\
\hline EM Excess Return & -19.06 & $1988-2013$ \\
\hline Global GDP Growth & -5.91 & $1970-2013$ \\
\hline Global Debt/GDP & 37.03 & $1970-2013$ \\
\hline Dollar Currency Risk & 16.51 & $1970-2013$ \\
\hline VIX & 31.87 & $1990-2013$ \\
\hline
\end{tabular}




\section{Table III. Cross-Country Evidence of International Instability Risk}

This table presents the markets' exposure to international instability risk (IIR) and the associated price of risk estimated using the Fama-MacBeth (1973) two-pass regressions. Test assets are excess returns of the 44 MSCI country indices. Panel A reports the countries' factor loadings on IIR from time series regressions: $R_{i, t}^{e}=\alpha_{i}+\beta_{i} I I R_{t}+\epsilon_{i, t}$. Panel B provides the market price of IIR from cross-sectional regressions: $R_{i, t}^{e}=\lambda_{0, t}+\lambda_{t} \beta_{i}+\eta_{i, t}, \bar{\lambda}=\frac{1}{T} \sum_{t=1}^{T} \lambda_{t}$. Newey-West (1987) three-lag adjusted $t$-statistics are reported in parentheses. The sample period is from 1970-2013.

\begin{tabular}{|c|c|c|c|}
\hline \multicolumn{4}{|c|}{ Panel A. Factor Loadings } \\
\hline \multicolumn{2}{|c|}{ Developed Countries } & \multicolumn{2}{|c|}{ Emerging Countries } \\
\hline Australia & -0.79 & Brazil & -0.72 \\
\hline Austria & $-2.37 * * *$ & Chile & $-2.35 * * *$ \\
\hline Belgium & -1.34 & China & -2.70 \\
\hline Canada & -0.72 & Colombia & $-2.81 * *$ \\
\hline Denmark & -1.15 & Czech Republic & $-3.50 * * *$ \\
\hline Finland & 0.00 & Egypt & $-4.62 * * *$ \\
\hline France & -0.82 & Greece & $-3.60 * * *$ \\
\hline Germany & -0.91 & Hungary & $-3.61 *$ \\
\hline Hong Kong & -1.67 & India & $-3.85 * *$ \\
\hline Ireland & -1.32 & Indonesia & $-2.73 * *$ \\
\hline Israel & -0.41 & Korea & -0.52 \\
\hline Italy & -0.50 & Malaysia & -1.17 \\
\hline Japan & -0.42 & Mexico & $-1.86^{*}$ \\
\hline Netherlands & -1.15 & Peru & $-4.25 * * *$ \\
\hline New Zealand & -0.79 & Philippine & -1.71 \\
\hline Norway & -1.53 & Poland & $-9.96 *$ \\
\hline Portugal & -0.91 & Russia & -2.10 \\
\hline Singapore & -1.67 & South Africa & $-3.81 * * *$ \\
\hline Spain & -0.41 & Taiwan & -1.30 \\
\hline Sweden & -0.41 & Thailand & $-2.71 * *$ \\
\hline Switzerland & -0.82 & Turkey & $-6.77 * *$ \\
\hline UK & -1.12 & & \\
\hline USA & -0.69 & & \\
\hline \multicolumn{4}{|c|}{ Panel B. The Market Risk of IIR } \\
\hline \multicolumn{2}{|l|}{ Price of Risk $(\lambda)$} & \multicolumn{2}{|c|}{$-4.56 * *$} \\
\hline \multirow{3}{*}{ Intercept } & & \multicolumn{2}{|c|}{$(-2.07)$} \\
\hline & & \multicolumn{2}{|c|}{5.94} \\
\hline & & \multicolumn{2}{|c|}{$(1.70)$} \\
\hline Adjusted $R^{2}(\%)$ & & \multicolumn{2}{|c|}{7.52} \\
\hline
\end{tabular}

\footnotetext{
*** Significant at the 0.01 level.

** Significant at the 0.05 level.

* Significant at the 0.10 level.
} 


\section{Table IV. Cross-Sectional GMM Estimation}

This table presents the coefficients of the Fama-MacBeth (1973) regressions estimated using the generalized method of moments (GMM). Test assets are the excess returns of the MSCI Emerging Markets Index (EMI) and the MSCI World Index (WI). The moment conditions, following Jagannathan and Wang (2002), are:

$$
E\left[\begin{array}{c}
R^{e}-\beta^{\prime}\left(\lambda-\mu+I I R_{t}\right) \\
\left(R^{e}-\beta^{\prime}\left(\lambda-\mu+I I R_{t}\right)\right) f_{t} \\
I I R_{t}-\mu
\end{array}\right]=\left[\begin{array}{l}
0 \\
0 \\
0
\end{array}\right],
$$

where IIR is the international instability risk factor proxied by the growth of global military expenditures scaled by global GDP, $\beta$ is vector of risk loadings, and $\lambda$ is the market price of IIR. Factor loadings and price of risk are presented in Panels A and B, respectively, with Newey-West (1987) three-lag adjusted $t$-statistics in parentheses. Wald test statistics of $\beta_{D}=\beta_{E}$ with the associated $p$-value are also reported. The sample period is from 1970-2013.

\begin{tabular}{lc}
\hline & Panel A. Factor Loadings \\
\hline Developed Markets $\left(\beta_{D}\right)$ & $-0.72^{* * *}$ \\
& $(-2.11)$ \\
Emerging Markets $\left(\beta_{E}\right)$ & $-1.59^{* * *}$ \\
Wald-test $\left(\beta_{D}=\beta_{E}\right)$ & $(-3.36)$ \\
& 0.11 \\
& Panel B. Market Price of IIR \\
\hline Price of Risk $(\lambda)$ & $(0.74)$ \\
\hline
\end{tabular}

*** Significant at the 0.01 level.

** Significant at the 0.05 level.

* Significant at the 0.10 level. 


\section{Table V. Robustness Tests}

This table presents results of robustness tests for international instability risk's (IIR) pricing power on international stock market returns using Fama-MacBeth (1973) regressions. Test assets are the excess returns of 44 MSCI country stock indices. In Columns (2)-(7), we conduct robustness tests by including control variables as additional pricing factors. Five control variables are considered: the excess returns of the MSCI World Index, the dollar factor, the global GDP growth, the growth of U.S. military expenditures as a percentage of GDP, and the growth of global debt over GDP ratio. Columns (8) and (9) provide the market prices estimated for the unexpected and the expected component of the IIR with all control variables included. Market prices of international instability risk and other control variables are reported with Newey-West (1987) three-lag adjusted $t$-statistics in parentheses. The sample period is from 1970-2013.

\begin{tabular}{|c|c|c|c|c|c|c|c|c|c|}
\hline & (1) & (2) & (3) & (4) & (5) & (6) & (7) & (8) & (9) \\
\hline \multirow[t]{2}{*}{$I I R$} & $-4.65 * *$ & $-4.51 *$ & $-4.52 * *$ & $-4.39 * *$ & $-5.01 * *$ & $-4.34 * *$ & $-5.74 * *$ & & \\
\hline & $(-2.07)$ & $(-1.95)$ & $(-2.04)$ & $(-1.97)$ & $(-2.06)$ & $(-2.00)$ & $(-2.24)$ & & \\
\hline \multirow[t]{2}{*}{$I I R^{u}$} & & & & & & & & $-4.37 * *$ & \\
\hline & & & & & & & & $(-2.15)$ & \\
\hline \multirow{2}{*}{$I I R^{e}$} & & & & & & & & & -0.76 \\
\hline & & & & & & & & & $(-1.08)$ \\
\hline \multirow{2}{*}{ Global Market Risk } & & $12.65 * *$ & & & & & $13.70 * *$ & $12.21 * *$ & $11.63 * *$ \\
\hline & & $(2.49)$ & & & & & $(2.49)$ & $(2.13)$ & $(2.18)$ \\
\hline \multirow[t]{2}{*}{ Currency Risk } & & & -1.98 & & & & -2.98 & -1.6 & -1.59 \\
\hline & & & $(-1.01)$ & & & & $(-1.24)$ & $(-0.60)$ & $(-0.65)$ \\
\hline \multirow[t]{2}{*}{ Global GDP Growth } & & & & $3.72 * *$ & & & $3.04 *$ & $3.53 * *$ & $3.10 * *$ \\
\hline & & & & $(2.05)$ & & & (1.92) & (2.39) & (2.07) \\
\hline \multirow[t]{2}{*}{ U.S. Militarization } & & & & & -3.35 & & $-4.30 *$ & -3.25 & -2.78 \\
\hline & & & & & $(-1.39)$ & & $(-1.8)$ & $(-1.30)$ & $(-1.26)$ \\
\hline \multirow[t]{2}{*}{ Global Debt/GDP } & & & & & & $-3.50 *$ & $-3.71 *$ & $-3.46^{*}$ & -3.08 \\
\hline & & & & & & $(-1.94)$ & $(-1.70)$ & $(-1.66)$ & $(-1.46)$ \\
\hline \multirow[t]{2}{*}{ Intercept } & $5.94 *$ & -4.55 & 5.56 & 1.21 & 4.81 & 2.78 & -6.75 & -4.38 & -3.16 \\
\hline & (1.70) & $(-0.76)$ & (1.58) & $(0.26)$ & (1.15) & $(0.72)$ & $(-1.23)$ & $(-0.87)$ & $(-0.64)$ \\
\hline Adjusted $R^{2}(\%)$ & 7.52 & 12.74 & 15.48 & 16.68 & 12.88 & 13.67 & 36.98 & 37.00 & 38.11 \\
\hline
\end{tabular}

*** Significant at the 0.01 level.

** Significant at the 0.05 level.

* Significant at the 0.10 level. 


\section{Table VI. The Instability Mimicking Portfolio: Model Comparison}

This table compares the time series pricing performance of the instability mimicking portfolio (IMP) with several alternative models including the CAPM, the Fama-French (1993) three-factor model, and the four-factor model that includes the Fama-French three factors and the momentum factor. The instability risk mimicking portfolio is constructed by projecting the international instability factor onto the space of traded returns. Test assets are monthly excess returns of 44 MSCI country stock indices. Panel A compares the mean absolute pricing error $\left(M A P E=\frac{1}{N} \sum_{i=1}^{N}\left|\alpha_{i}\right|\right)$ under each model specification. All presented returns are in annual percentage terms. We also report the GRS (Gibbons, Ross, and Shanken, 1989) $F$-statistics, which tests the hypothesis of the alphas being jointly zero with the corresponding $p$-value in square brackets. Panel B reports the annualized cross-sectional intercept with Newey-West (1987) three-lag adjusted $t$-statistics in parentheses. The sample period is from January 1991-January 2015.

\begin{tabular}{|c|c|c|c|c|c|}
\hline \multicolumn{6}{|c|}{ Panel A. Time Series Alphas } \\
\hline & Mean & IMP & $C A P M^{G}+E M$ & $F F^{G}+E M$ & $F F^{G}+M M T^{G}+E M$ \\
\hline MAPE & 9.71 & 4.75 & 3.92 & 3.92 & 4.35 \\
\hline GRS & & 1.14 & 1.68 & 1.72 & 1.70 \\
\hline$p$-value & & {$[0.26]$} & {$[0.01]$} & {$[0.01]$} & {$[0.01]$} \\
\hline \multicolumn{6}{|c|}{ Panel B. Cross-Sectional Intercepts } \\
\hline & & $I M P$ & $C A P M^{G}+E M$ & $F F^{G}+E M$ & $F F^{G}+M M T^{G}+E M$ \\
\hline Intercept & & -0.81 & 1.43 & 2.04 & 3.40 \\
\hline$t$-statistic & & $(-0.17)$ & $(0.28)$ & $(0.40)$ & $(0.68)$ \\
\hline Adjusted $R^{2}(\%)$ & & 5.42 & 13.23 & 15.04 & 21.70 \\
\hline
\end{tabular}

\footnotetext{
*** Significant at the 0.01 level.

** Significant at the 0.05 level.

* Significant at the 0.10 level.
} 


\section{Table VII. Alternative Measures of International Instability Risk}

This table presents the pricing power on international stock market returns using alternative measures of the international instability risk. Panel A defines each alternative proxy. Panel B presents the results estimated using the Fama-MacBeth (1973) two-pass regressions and the excess returns of 44 MSCI country stock indices as test assets. Panel C provides the results estimated using the GMM method with excess returns of the MSCI Emerging Markets Index (EMI) and the MSCI World Index (WI) as test assets. Market prices of international instability risk and the cross-sectional intercepts are reported with $t$-statistics in parentheses. Statistical significance is determined based on Newey-West (1987) three-lag adjusted standard errors. The sample period is from 1970-2013.

\begin{tabular}{|c|c|c|c|c|c|}
\hline \multicolumn{6}{|c|}{ Panel A. Notations } \\
\hline IIR & \multicolumn{5}{|c|}{ The growth rate of global military expenditures scaled by GDP. } \\
\hline Proxy 1 & \multicolumn{5}{|c|}{ Residuals from projecting the IIR on the growth rate of global GDP per capita. } \\
\hline Proxy 2 & \multicolumn{5}{|c|}{ Residuals from projecting the IIR on the dollar factor. } \\
\hline Proxy 3 & \multicolumn{5}{|c|}{$\begin{array}{l}\text { Residuals from projecting the IIR on the growth rate of global GDP per capita and the dollar } \\
\text { factor. }\end{array}$} \\
\hline Proxy 4 & \multicolumn{5}{|c|}{ The GDP weighted standard deviation of country-level military expenditures to GDP ratio. } \\
\hline \multicolumn{6}{|c|}{ Panel B. 44 MSCI Country Stock Indices as Test Assets } \\
\hline & IIR & Proxy 1 & Proxy 2 & Proxy 3 & Proxy 4 \\
\hline \multirow{2}{*}{ Price of Risk $(\lambda)$} & $-4.65 * *$ & $-4.36 * *$ & $-4.16 * *$ & $-4.11 * *$ & $-2.90 *$ \\
\hline & $(-2.07)$ & $(-2.00)$ & $(-1.94)$ & $(-1.93)$ & $(-1.85)$ \\
\hline \multirow[t]{2}{*}{ Intercept } & $5.94 *$ & $6.60 * *$ & $7.01 * *$ & $7.11 * *$ & $9.76 * *$ \\
\hline & $(1.70)$ & $(1.97)$ & $(2.03)$ & $(2.07)$ & $(2.88)$ \\
\hline Adjusted $R^{2}(\%)$ & 7.52 & 7.40 & 6.90 & 6.88 & 4.60 \\
\hline \multicolumn{6}{|c|}{ Panel C. The MSCI EMI and WI as Test Assets } \\
\hline & IIR & Proxy 1 & Proxy 2 & Proxy 3 & Proxy 4 \\
\hline \multirow{2}{*}{ Developed Markets $\left(\beta_{D}\right)$} & $-0.72 * *$ & $-0.65^{* *}$ & $-0.63 * *$ & $-0.62 * *$ & -0.27 \\
\hline & $(-2.11)$ & $(-2.11)$ & $(-2.15)$ & $(-2.15)$ & $(-0.78)$ \\
\hline \multirow[t]{2}{*}{ Emerging Markets $\left(\beta_{E}\right)$} & $-1.59 * * *$ & $-1.49 * * *$ & $-1.42 * * *$ & $-1.40 * * *$ & -0.58 \\
\hline & $(-3.36)$ & $(-3.27)$ & $(-3.05)$ & $(-3.04)$ & $(-0.76)$ \\
\hline \multirow[t]{2}{*}{ Price of Risk $(\lambda)$} & $-8.40 * * *$ & $-9.22 * * *$ & $-9.62 * * *$ & $-9.71 * * *$ & -24.78 \\
\hline & $(-2.78)$ & $(-2.73)$ & $(-2.75)$ & $(-2.74)$ & $(-0.78)$ \\
\hline
\end{tabular}

\footnotetext{
*** Significant at the 0.01 level.

** Significant at the 0.05 level.

* Significant at the 0.10 level.
} 


\section{Table VIII. Cross-Country Evidence of International Instability Risk: Subsample Excluding the Financial Crisis}

This table provides the results of subsample tests for international instability risk's (IIR) pricing power on international stock market returns excluding the 2007-2009 financial crisis. Panel A presents results using IIR as the only pricing factor, while Panel B reports results with the control variables as additional pricing factors. Then five control variables are the excess returns of the MSCI World Index, the dollar factor, the global GDP growth, the growth of U.S. military expenditures as a percentage of GDP, and the growth of global debt over GDP ratio. Market prices of international instability risk and the cross-sectional intercepts are reported with Newey-West (1987) three-lag adjusted $t$-statistics in parentheses.

\begin{tabular}{|c|c|c|c|c|c|}
\hline \multicolumn{6}{|c|}{ Panel A. Pricing Results without Controls } \\
\hline & \multirow[b]{2}{*}{$1970-2013$} & \multicolumn{4}{|c|}{ Excluding the Financial Crisis } \\
\hline & & $\begin{array}{c}\text { Excl. } \\
2007-2009\end{array}$ & Excl. 2007 & Excl. 2008 & Excl. 2009 \\
\hline Price of risk $(\lambda)$ & $\begin{array}{l}-4.65 * * \\
(-2.07)\end{array}$ & $\begin{array}{l}-3.83 \\
(-1.64)\end{array}$ & $\begin{array}{l}-4.65 * * \\
(-2.02)\end{array}$ & $\begin{array}{c}-3.79 * \\
(-1.70)\end{array}$ & $\begin{array}{l}-4.70 * * \\
(-2.02)\end{array}$ \\
\hline Intercept & $\begin{array}{c}5.94 * \\
(1.70)\end{array}$ & $\begin{array}{l}10.34 * * * \\
(3.29)\end{array}$ & $\begin{array}{c}5.68 * \\
(1.60)\end{array}$ & $\begin{array}{l}11.30 * * * \\
(3.38)\end{array}$ & $\begin{array}{l}5.37 \\
(1.50)\end{array}$ \\
\hline Adjusted $R^{2}(\%)$ & 7.52 & 6.05 & 7.48 & 6.02 & 7.20 \\
\hline \multicolumn{6}{|c|}{ Panel B. Pricing Results with Controls } \\
\hline & & \multicolumn{4}{|c|}{ Excluding the Financial Crisis } \\
\hline & $1970-2013$ & $\begin{array}{c}\text { Excl. } \\
\text { 2007-2009 }\end{array}$ & Excl. 2007 & Excl. 2008 & Excl. 2009 \\
\hline Price of risk $(\lambda)$ & $\begin{array}{l}-5.74 * * \\
(-2.24)\end{array}$ & $\begin{array}{c}-5.29 * \\
(-1.88)\end{array}$ & $\begin{array}{l}-5.75 * * \\
(-2.15)\end{array}$ & $\begin{array}{c}-4.82 * \\
(-1.91)\end{array}$ & $\begin{array}{l}-6.25 * * \\
(-2.24)\end{array}$ \\
\hline Global market risk & $\begin{array}{l}13.70 * * \\
(2.49)\end{array}$ & $\begin{array}{c}7.99 \\
(1.50)\end{array}$ & $\begin{array}{l}13.33 * * \\
(2.37)\end{array}$ & $\begin{array}{r}9.44 * \\
(1.91)\end{array}$ & $\begin{array}{l}13.45 * * \\
(2.29)\end{array}$ \\
\hline Currency risk & $\begin{array}{c}-2.98 \\
(-1.24)\end{array}$ & $\begin{array}{c}-4.34 \\
(-1.46)\end{array}$ & $\begin{array}{l}-3.18 \\
(-1.30)\end{array}$ & $\begin{array}{l}-3.69 \\
(-1.44)\end{array}$ & $\begin{array}{l}-3.52 \\
(-1.25)\end{array}$ \\
\hline Global GDP growth & $\begin{array}{l}3.04 * \\
(1.92)\end{array}$ & $\begin{array}{c}1.69 \\
(1.20)\end{array}$ & $\begin{array}{c}2.86 * \\
(1.82)\end{array}$ & $\begin{array}{c}2.09 \\
(1.36)\end{array}$ & $\begin{array}{c}2.97 * \\
(1.90)\end{array}$ \\
\hline US militarization & $\begin{array}{c}-4.30 * \\
(-1.80)\end{array}$ & $\begin{array}{r}-4.12 * \\
(-1.66)\end{array}$ & $\begin{array}{l}-4.35^{*} \\
(-1.78)\end{array}$ & $\begin{array}{c}-3.62 \\
(-1.57)\end{array}$ & $\begin{array}{l}-4.77 * \\
(-1.91)\end{array}$ \\
\hline Global debt/GDP & $\begin{array}{c}-3.71 * \\
(-1.70)\end{array}$ & $\begin{array}{l}-1.61 \\
(-1.04)\end{array}$ & $\begin{array}{l}-3.76^{*} \\
(-1.67)\end{array}$ & $\begin{array}{l}-1.55 \\
(-1.05)\end{array}$ & $\begin{array}{c}-3.78 * \\
(-1.73)\end{array}$ \\
\hline Intercept & $\begin{array}{c}-6.75 \\
(-1.23)\end{array}$ & $\begin{array}{c}0.71 \\
(0.15)\end{array}$ & $\begin{array}{l}-6.36 \\
(-1.13)\end{array}$ & $\begin{array}{c}-0.27 \\
(-0.06)\end{array}$ & $\begin{array}{c}-7.13 \\
(-1.27)\end{array}$ \\
\hline Adjusted $R^{2}(\%)$ & 36.98 & 38.43 & 37.33 & 38.67 & 36.77 \\
\hline
\end{tabular}

\footnotetext{
*** Significant at the 0.01 level.

** Significant at the 0.05 level.

* Significant at the 0.10 level.
} 


\section{Table IX. U.S. Evidence}

This table reports results of U.S. stock portfolios. Test assets are the excess returns of the 25 Fama-French (1993) portfolios formed on size and book-to-market ratio plus the 17 industry portfolios. Regression (1) uses the international instability risk factor as the pricing factor. Regression (2) corresponds to the regression using the growth of U.S. military expenditures to the GDP ratio as the pricing factor. Regressions (3)-(7) are robustness tests for Regression (2). In each robustness test, one (or more) control variable(s) is (are) included as an additional factor(s). Four control variables are considered: excess returns of the market portfolio, the growth rate of U.S. debt over GDP (US Debt/GDP), the real excess returns of the top three military contractors in the U.S. (Mil. Contractor), and the real excess returns of U.S. defense stocks over the market return (Defense Portfolio). The estimated market prices of risks are reported in percentage with Newey-West (1987) three-lag adjusted $t$-statistics in parentheses. The sample period is from 1970-2013 for Regression (1), and 19302013 for Regressions (2)-(7).

\begin{tabular}{|c|c|c|c|c|c|c|c|}
\hline & (1) & (2) & (3) & (4) & (5) & (6) & (7) \\
\hline IIR & $\begin{array}{c}4.18 \\
(1.52)\end{array}$ & & & & & & \\
\hline U.S. Militarization & & $\begin{array}{c}-44.52^{*} \\
(-1.81)\end{array}$ & $\begin{array}{c}-20.31 \\
(-1.19)\end{array}$ & $\begin{array}{c}-45.43 * \\
(-1.92)\end{array}$ & $\begin{array}{c}-47.41 * \\
(-1.90)\end{array}$ & $\begin{array}{c}-27.01 \\
(-1.21)\end{array}$ & $\begin{array}{c}5.85 \\
(0.38)\end{array}$ \\
\hline U.S. Mkt-rf & & & $\begin{array}{c}7.33^{*} \\
(1.86)\end{array}$ & & & & $\begin{array}{c}2.44 \\
(0.64)\end{array}$ \\
\hline U.S. Debt/GDP & & & & $\begin{array}{l}-1.97 \\
(-0.60)\end{array}$ & & & $\begin{array}{c}4.14 \\
(1.55)\end{array}$ \\
\hline Mil. Contractor & & & & & $\begin{array}{r}6.70 * \\
(1.78)\end{array}$ & & $\begin{array}{c}2.79 \\
(0.71)\end{array}$ \\
\hline Defense Portfolio & & & & & & $\begin{array}{l}16.41 * * * \\
(3.60)\end{array}$ & $\begin{array}{l}13.85^{* * * *} \\
(3.39)\end{array}$ \\
\hline Intercept & $\begin{array}{l}10.02 * * * \\
(3.72)\end{array}$ & $\begin{array}{c}5.94 * * \\
(2.79)\end{array}$ & $\begin{array}{c}2.22 \\
(0.69)\end{array}$ & $\begin{array}{l}6.55^{* *} \\
(2.65)\end{array}$ & $\begin{array}{l}5.60 * * \\
(2.56)\end{array}$ & $\begin{array}{l}6.58 * * * \\
(3.15)\end{array}$ & $\begin{array}{c}5.54^{*} \\
(1.77)\end{array}$ \\
\hline Adjusted $R^{2}(\%)$ & 13.56 & 10.45 & 20.39 & 17.03 & 14.47 & 18.52 & 35.80 \\
\hline
\end{tabular}

\footnotetext{
*** Significant at the 0.01 level.

** Significant at the 0.05 level.

* Significant at the 0.10 level.
} 